ISSN 2073-4409

www.mdpi.com/journal/cells

Review

\title{
DNA Methylation and Apoptosis Resistance in Cancer Cells
}

\section{Eric Hervouet ${ }^{1}$, Mathilde Cheray ${ }^{2,3}$, François Marie Vallette ${ }^{2,3,4}$ and Pierre-François Cartron ${ }^{2,3, *}$}

1 Laboratoire de Biochimie, EA3922, UFR-ST, Université de Franche-Comté, 25035 Besançon

Cedex, France; E-Mail: eric.hervouet@univ-fcomte.fr

2 Centre de Recherche en Cancérologie Nantes-Angers, INSERM, U892, Equipe Apoptose et progression tumorale, Equipe labellisée Ligue Nationale Contre le Cancer, 44007 Nantes, France;

3 Université de Nantes, Faculté de Médecine, Département de Recherche en Cancérologie, IFR26, F-4400, Nantes, France; E-Mail: mathilde.cheray@univ-nantes.fr

4 LaBCT, Institut de Cancérologie de l'Ouest, Nantes, Saint Herblain Cedex, France;

E-Mail: Francois.Vallette@univ-nantes.fr

* Author to whom correspondence should be addressed; E-Mail: Pierre-francois.cartron@inserm.fr; Tel.: +33-22-808-0327; Fax: +33-22-808-0204.

Received: 25 May 2013; in revised form: 27 June 2013 / Accepted: 28 June 2013 /

Published: 18 July 2013

\begin{abstract}
Apoptosis is a cell death programme primordial to cellular homeostasis efficiency. This normal cell suicide program is the result of the activation of a cascade of events in response to death stimuli. Apoptosis occurs in normal cells to maintain a balance between cell proliferation and cell death. A deregulation of this balance due to modifications in the apoptosic pathway leads to different human diseases including cancers. Apoptosis resistance is one of the most important hallmarks of cancer and some new therapeutical strategies focus on inducing cell death in cancer cells. Nevertheless, cancer cells are resistant to treatment inducing cell death because of different mechanisms, such as DNA mutations in gene coding for pro-apoptotic proteins, increased expression of anti-apoptotic proteins and/or pro-survival signals, or pro-apoptic gene silencing mediated by DNA hypermethylation. In this context, aberrant DNA methylation patterns, hypermethylation and hypomethylation of gene coding for proteins implicated in apoptotic pathways are possible causes of cancer cell resistance. This review highlights the role of DNA methylation of apoptosis-related genes in cancer cell resistance.
\end{abstract}

Keywords: apoptosis; DNA methylation; cancer; epigenetic 


\section{Introduction}

Apoptosis or programmed cell death is a key suicide program dominant in the maintenance of cellular homeostasis and is initiated by the activation of a cascade of events preexisting within each cell, in response to death stimuli. Apoptosis contributes to a balance between cell proliferation and cell death in normal cells and disturbances in this pathway are often observed in human diseases. Among the hallmarks characterizing tumor escape (tumor reccurence despite resection and treatments) [2], apoptosis resistance is one of the most striking. Furthermore, even if new therapeutical strategies have emerged over the last decades to force cancer cells to undergo cell death, apoptosis resistance to treatment is still a major problem in cancer research and requires extensive research to improve our knowledge of apoptosis signaling. Cancers cells have developed numerous strategies of resistance to cell death such as DNA mutations in genes coding for pro-apoptotic proteins, increase expression of anti-apoptotic proteins and/or pro-survival signals, or discovered more recently, pro-apoptic gene silencing mediated by DNA hypermethylation. DNA methylation occur in about $50 \% \mathrm{CpG}$ in the genome and results from a transfer of a $\mathrm{CH} 3$ (methyl group) from S-adenosyl methionine to the fifth carbon of cytosine in $\mathrm{CpG}$ motifs. $\mathrm{CpG}$-rich areas referred as $\mathrm{CpG}$ islands (CGI) are more frequently methylated than isolated $\mathrm{CpG}$ and is generally associated with gene repression. Two distinct mechanisms of DNA methylation have been reported. The first is maintaining DNA methylation, which occurs on neosynthesized strands of DNA following replication and is mainly catalyzed by DNA methyltransferase 1 (Dnmt1) [3]. The second process is de novo (dn) methylation, which occurs on both strands of unmethylated DNA and is predominantly catalyzed by Dnmt3a and Dnmt3b [4]. Epigenetics appears highly implicated in gene dysregulation in cancers. Many cancers are characterized by global DNA hypomethylation [5,6], previously associated with chromosomal instability, and paradoxically with both local hypo and hypermethylations [7-9]. It is now well known that local hypomethylation may lead to abnormal activation of genes including oncogenes while hypermethylation could silence tumor suppressor genes (TSG) [10,11]. Similar phenomenon occur in genes regulating the apoptosis pathway and these epigenetic modifications could influence the balance between pro- and anti-apoptotic protein expression conferring a phenotype of apoptosis resistance in cancer cells. Indeed, hypermethylation of a number of genes implicated in the apoptosic pathway has been reported in cancer cells (Table 1). Among them, some seem more specific to a tumor type while others appear commonly methylated in cancers as illustrated by the methylation of Puma in lymphoma [12] while $D A P K$ or RASSF1A methylations have been found in most cancers analyzed (Table 1). Moreover, hypermethylation of these genes could occur sporadically in tumors or cover a large sequence of the promoter and are found from low to high frequencies in cancer patients (Table 1). Owing to pleiotropic effects of p53 silencing in cancers, methylation of this gene has not been considered in this review (For a review, cf [13]). 
Table 1. Apoptosis related genes are frequently methylated in tumors. Percentage of methylated tumors is indicated in brackets for significant histochemical studies.

\begin{tabular}{|c|c|c|}
\hline $\begin{array}{c}\text { Gene } \\
\text { methylated }\end{array}$ & Cancer & Ref \\
\hline APAF-1 & $\begin{array}{l}\text { Melanoma, Leukemia, Testicular (100 vs. 60), Bladder (11), RCC } \\
\text { (100) }\end{array}$ & {$[14],[15],[16],[17],[18]$} \\
\hline $\mathrm{Bad}$ & Myeloma & [19] \\
\hline Bak & Myeloma & [19] \\
\hline Bax & GBM, Myeloma & {$[20],[19]$} \\
\hline Bcl2L10 & Gastric (38), Leukemia (12-45) & [21], [22] \\
\hline Bim & CML & [23] \\
\hline Bik & Glioma (30), HCC, RCC, Prostate, Myeloma & {$[24],[25],[26],[27]$} \\
\hline BNIP3 & $\begin{array}{l}\text { Pancreatic, Gastric (39), Breast, Colorectal, Leukemia, Myeloma, } \\
\text { HCC }\end{array}$ & {$[28],[29],[30],[31]$} \\
\hline Casp-8 & $\begin{array}{l}\text { Medulloblastoma (62-81), Pituitary tract (54), Rhabdosarcoma (83 vs } \\
\text { 0), Phaeochromocytoma (31), Neuroblastoma (35-52 vs 0), } \\
\text { Retinoblastoma ( } 59 \text { vs. 0), HCC (34), GBM (30), Bladder (19), Lung } \\
(0-45 \text { vs. 0), Rectal, Breast, Prostate, Gastric }\end{array}$ & $\begin{array}{l}{[32],[33],[34],[35],[36],[37],} \\
{[38],[39],[40],[41]}\end{array}$ \\
\hline DAPK & $\begin{array}{l}\text { Mesothelioma (20), Testicular (20-50 vs. 6), Nasopharyngial (76 vs. } \\
\text { 0), Pituitary (43), Colorectal (81), ACC (27), Lung (25-44), Biliary } \\
\text { tract (21), Lymphoma (71-85), GBM (14), Gastric (22-70), } \\
\text { Leukemia (36), Breast (13-88), CXCA (56-79), Cholangiocarcinoma } \\
\text { (31), Bladder (74-77), RCC (33-55), Head and Neck (11-33), } \\
\text { Myeloma (40), Oesophageal (50-60 vs. 20), Ovarian }\end{array}$ & $\begin{array}{l}{[42],[43],[44],[45],[46],[47],} \\
{[48],[49],[16],[50],[36],[51],} \\
{[52],[53]}\end{array}$ \\
\hline DcR1-2 & $\begin{array}{l}\text { Glioma (60), Neuroblatoma (11-25), Prostate (50), Breast, Prostate } \\
\text { (37-45), Ovarian (31-43), Breast (70), Lung (31), Mesothelioma } \\
\text { (63), Bladder (42), CXCA (100), Lymphoma (41), Leukemia (26), } \\
\text { Myeloma (56), Phaeochromocytoma (23-26) }\end{array}$ & $\begin{array}{l}{[54],[32],[55],[56],[57],[58],} \\
{[37]}\end{array}$ \\
\hline DR4 or 5 & $\begin{array}{l}\text { Breast, Melanoma, Ovarian (10-28), Phaeochromocytoma (41), } \\
\text { Neuroblastoma }\end{array}$ & [54], [59], [60], [37], [61] \\
\hline Fas & Lymphomas, CXCA, Colon, Prostatic (12), Lung & [62], [63], [64], [65] \\
\hline Hrk & $\begin{array}{l}\text { Colorectal (36), Gastric (32), GBM (27-43), PCNSL (31), Prostate } \\
\text { (38) }\end{array}$ & {$[66],[67],[68],[69]$} \\
\hline Puma & Lymphoma & {$[12]$} \\
\hline RASSF1a & $\begin{array}{l}\text { ACC (42-45), Biliary tract (27), CRCC (45), Nasopharyngeal (71-84 } \\
\text { vs. 0), Ovarian (26), Gastric, Bladder (48-60 vs. 42), Thyroid, } \\
\text { Neuoblastoma (83-93), Osteosarcoma (14 vs. 1), Lung (43 vs. 5), } \\
\text { Breast (63-74), , HCC Hepatoblastoma (39-44), CXCA (26 vs. 0), } \\
\text { Mesothelioma, Glioma (12-82), Endometrial, Liver (38), Prostate, } \\
\text { Parathiroid (98), Lung (26), Testis (78 vs. 0), Melanoma (69), } \\
\text { Colorectal (31), Retinoblastoma (98) }\end{array}$ & $\begin{array}{l}{[70],[71],[72],[73],[74],[75],} \\
{[76],[32],[77],[78],[79],[80],} \\
{[81],[82],[56],[83]}\end{array}$ \\
\hline SARP2 & Pancreatic (90-90 vs. 0-5), Colorectal, Oesophageal & [84] \\
\hline
\end{tabular}


Table 1. Cont.

\begin{tabular}{|c|c|c|}
\hline $\begin{array}{c}\text { Gene } \\
\text { methylated }\end{array}$ & Cancer & Ref \\
\hline TMS1 & $\begin{array}{l}\text { Cholangiocarcinoma (36), Prostatic (47-65), Colorectal (25-41 vs. } \\
\text { 8), Ovarian (19 vs. 0), Thyroid (33), Breast (24-46), Gastric ( } 32 \text { ), } \\
\text { GBM (21-57), Lung (41-70), Melanoma, Colorectal, Neuoblastoma, } \\
\text { HCC, Pancreatic }\end{array}$ & $\begin{array}{l}{[85],[86],[87],[88],[89],[55]} \\
{[90],[91],[92],[93],[94]}\end{array}$ \\
\hline TNFR10c & $\begin{array}{l}\text { Pancreatic (54-97), Choroid plexus (50), Neuroblastoma (21), Breast } \\
\text { (48), Lung (37), Mesothelioma (43), Ependymomas (50) }\end{array}$ & [95] \\
\hline $\mathrm{XAF}-1$ & $\begin{array}{l}\text { Colorectal (40), Gastric, Bladder, RCC, Prostatic (35 vs. 0), Lung, } \\
\text { GBM (22), Oesophageal }\end{array}$ & [96], [97], [98], [99], [34], [100] \\
\hline
\end{tabular}

\section{Apoptotic Pathways}

Both the intrinsic and extrinsic pathway of apoptosis have been reported in mammals (Figure 1). Briefly, the intrinsic pathway involves a diverse array of non-receptor-mediated stimuli that produce intracellular signals that act directly on targets within the cell and are mitochondrial-initiated events which can be activated by the TSG p53 in response to cell injury such as DNA damage following radiation exposure. The $\mathrm{Bcl} 2$ protein family is composed of pro-apoptotic and anti-apoptotic members and are classified in three subfamilies with regards to their Bcl2 homology domains (BH). Bax and Bak present 3 BH domains (BH1-3) and are associated with pro-apoptotic properties. Conversely, anti-apoptotic proteins $\mathrm{Bcl} 2$, BclXL, Mcl-1, A1 and Bcl-W present $4 \mathrm{BH}$ domains (BH1-4), and are capable of antagonizing Bax and Bak. Bim, Bik, Bad, Hrk, Noxa and Puma, which belong to the third subfamily (referred to BH3-only) and are devoided of BH1, 2 and 4. BH3-only proteins are also able to bind proapoptotic proteins (like Bax and Bak) and activate or block their activity. Following the initiation of apoptosis, Bax and Bak undergo a conformational change, which consequently induces a permeabilization of the outer mitochondrial membrane releasing several mitochondrial proteins from intermembrane space (cytochrome c, Smac/diablo, HtrA2/omi). Interaction of APAF-1 with cytochrome $\mathrm{c}$ and proCasp 9 leads to the formation of the Apoptosome complex and the activation of Casp 9. Finally, cleavage of effector proCasp3 and pro-Casp7 into active Casp3 and 7 and nuclear fragmentation causes the formation of apoptotic bodies. The extrinsic pathway is activated in response to cytokines. Tumor necrosis factor-related apoptosis-inducing ligand (TRAIL or Apo2 ligand) is able to selectively induce apoptosis in tumor cells with no significant untoward effect on normal cells. Apoptosis induced by TRAIL is initiated by its binding to death receptors (TRAIL-R1 or DR4 and TRAIL-R2 or DR5) followed by formation of the death-inducing signalling complex (DISC) upon recruitment of specific cytoplasmic proteins, Fas-associated death domain (FADD) and caspase-8 or -10. Binding of FasL to the extracellular area of Fas (APO1/CD95) induces a conformational change in the receptor and a recruitment of FADD (Fas-interacting DD) and proCasp 8 and proCas 10 effectors in the cytoplasmic region of the receptor via its death domain. Formation of this complex induces an increased concentration of initiator caspases: proCasp 8 and 10 on Fas receptor and their automatic cleavage to active Casp 8 and 10. Once activated, these caspases can directly activate Casp 3 or connect to the intrinsic pathway by the cleavage of BID into tBID catalysed by Casp 8, which consequently leads to the activation of Bax and mitochondrial pathway and further Casp 3 activation. 
Figure 1. Mechanism of apoptosis. Activation of initiators caspase 8 and 10 are mediated in response to extrinsic stimuli and apoptosis signaling is controlled by anti- and pro-apoptotic protein interactions.

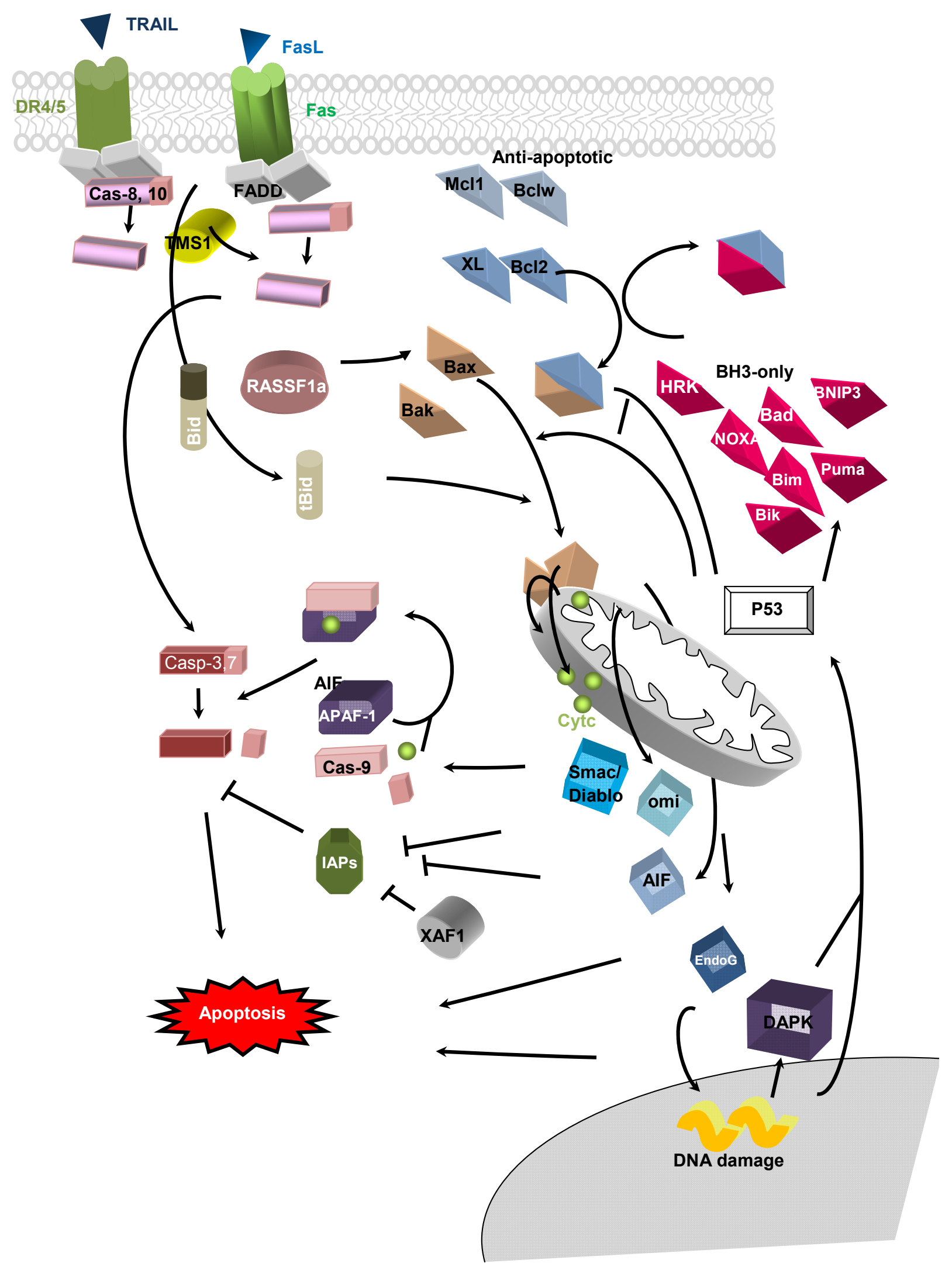




\section{DNA Hypo/Hypermethylations in Apoptosis-Related Genes in Cancer}

\subsection{Extrinsic Pathway}

\subsubsection{Death Receptor}

Aberrant methylation in the promoters of gene coding for proteins implicated in the extrinsic pathway could be responsible of early blocking events in apoptosis. A decrease in Fas expression has been observed in p53 mutated cancer cells. Two distinct regions controlling Fas expression are sensitive to methylation. The Fas promoter contain a 650 pb CGI (28 CpG sites) in the 5'flanking region and a second CGI in intron 1. Such aberrant methylation has been reported in Fas promoter in T-cell lymphoma or in colon carcinoma cell lines and also correlated to a decrease in Fas expression, thus conferring apoptosis resistance independently of the p53 status. Conflicting results have been reported on the correlation between methylation and Fas gene silencing. Butler et al. [101] proposed that in colorectal carcinomas Fas silencing might not be due to promoter methylation as they did not find any methylation in the $9 \mathrm{CpG}$ located in the Fas promoter. However, it should be noted that this study did not include a large area of the promoter, such as the $\mathrm{CpG}$ site at -548 position, the only $\mathrm{CpG}$ methylated in RKO cells, the demethylation of which by 5-azadeocytidine restored Fas expression and apoptosis. Specific methylation of p53 binding site in intron 1 may also explain the efficient Fas silencing in some colon cancers [64]. Aberrant methylation in the promoters of DcR1, DcR2, DR4 and $D R 5$ have been reported in neuroblastoma tissue or cell lines and inversely correlated to expression of these genes. TNFRSF10c belongs to the tumor necrosis factor receptor family and has also been frequently deleted in many cancers but silencing of the TNFRSF10C gene in pancreatic cancers occur predominantly by hypermethylation in $\mathrm{CpG}$ islands associated with apoptosis resistance [95].

\subsubsection{Caspase $8(\operatorname{Casp} 8)$}

Whereas, according to literature, methylation of $F a s$ or $D c R / D R$ genes are rare events, many reports have shown the frequent hypermethylation of the promoter of Casp 8 in many different cancers (Table 1). Methylation in the Casp 8 promoter generally correlated with a low Casp 8 expression, and low apoptosis sensitivity to trail and was reversed in different cancer cell lines as lung cancer cells, using a 5-azadeoxycytidine treatment, an inhibitor of DNA methylation. While mechanisms governing genes hypermethylation in cancers - in particular in apoptosis pathways are until now poorly understoodsome initial results have been proposed to explain the hypermethylation of the Casp 8 promoter. Kurita et al. [102] reported that both invalidation of Dnmt1 and Dnmt3b was required to reverse Casp 8 promoter methylation and induce gene reexpression in human hepatoma cells. However, we recently reported that Casp8 methylation correlated with both Dnmt1 and Dnmt3a, but not with Dnmt3b [34]. These reports strongly support a role for cooperation between Dnmt1 and $d n$ Dnmts in Casp8 methylation. The requirement of Dnmt3a or Dnmt3b might be governed by tissue or CpG specificity. Dnmt1/Dnmt3b cooperation has already been described for methylation of survival genes ( $p 16$, $B A G E 1, C X C L 12)$. Molecular mechanisms at the origin of Casp 8 methylation have been partially analyzed. The methylation in the SP1 box located at -97 position completely abolished SP1 complex recruitment and Casp 8 expression [103]. Similarly, in neuroblastoma, 63\% of tumors presenting 
c-MYCN oncoprotein amplification were also associated with methylation of Casp 8 whereas only $6 \%$ of tumors without c-MYCN amplification were methylated [104]. With regards to the new roles of TFs (Transcription Factors)/Dnmts interaction in gene silencing, these observations might suggest a role for SP1 and/or c-MYCN in Casp8 methylation. Moreover, few regulators of the extrinsic pathway are known. Methylation-dependent silencing of these proteins could also play a role in apoptosis resistance in cancer cells.

3.1.3. TMS1/ASC (target for methylation-induced silencing-1/apoptosis-associated speck-like protein containing CARD-ASC).

A CGI gene called TMS1/ASC encodes for a pro-apoptotic tumor suppressor protein composed of PYD (pyrine domain) and CARD motifs. Activation of TMS1 is able to induce apoptosis in a Casp 8-dependent manner (Figure 1). A high frequency of methylation was found in TMS1 promoter in many tumors and the density of methylation inversely correlated both, in tissue and cell lines, to TMS1 expression as illustrated in glioma cells [105]. Invalidation of TMS1 in cultured cells induced a partial protection against TRAIL-induced p53-mediated apoptosis, however, contribution of TMS1 methylation to cancer progression is not clear as no correlation could be found between methylation and pathological changes in several cancers including cholangiocarcinoma $[88,106]$. Since TMS1 methylation in normal tissue adjacent to prostate tumors was significantly more frequent in patients with biochemical recurrence, the TMS1 methylation event was suggested to contribute to aggressiveness in some cancers. The latter observation was validated in neuroblastoma patients showing links between TMS1 methylation and shorter survival curves [85,107]. TMS1 mediatedmethylation was significantly higher in clear cell ovarian tumors than in other ovarian cancer types, suggesting different roles of TMS1 inactivation in tumors from different tissues but also from the same organ [90]. Interestingly, Das et al. [108] reported a significant difference in methylation frequencies in TMS1 promoter in prostate cancers based on racial criteria (black or white) associated with a mortality ratio two-fold higher in the black male population. Environment, diet and ethnic habits are supposed to influence methylation status of genes and might contribute to epigenetic-mediated tumorigenesis. Silencing machinery controlling TMS1 methylation has been poorly studied. TMS1 silencing could result from dense methylation in CGI combined with hypoacetylation in $\mathrm{H} 3$ and $\mathrm{H} 4$ and the modification of the chromatin structure in CGI. In glioma patients, TMS1 methylation was correlated with Dnmt3b content and overexpression of Dnmt3b caused an increase in TMS1 methylation, while Dnmt3a overexpression had no effect. In glioma cells, corecruitment of Dnmt1, Dnmt3b and HDAC1 on the TMS1 promoter suggest a silencing complex requiring a cooperation between DNA methylation and hypoacetylation [34]. While no association was found between Dnmt1 and TMS1 expression, Dnmt1 is a member of the silencing complex; moreover, overexpression of Dnmt1 in fibroblast was also silenced in a DNA methylation manner the TMS1/ASC gene [109]. Indeed, recruitment of MBD3 on the TMS1 promoter in prostate cancers also suggested a role for the the NuRD complex in TMS1 silencing. 


\subsection{Intrinsic Pathway}

\subsubsection{Bax}

Methylation in the Bax promoter induced a strong decrease or complete silencing of Bax expression in glioma cells or glioma patients. Moreover, silencing of Bax by RNAi conferred a resistance to Fas ligand-mediated apoptosis in cell culture suggesting a role of methylation-mediated Bax silencing in apoptosis resistance in GBM. The low number of GBM patients presenting Bax silencing does not permit a serious statistical survival analysis [20,34]. However, it should be noted that in a cohort of 27 GBM patients, the patient presenting a Bax inactivation via methylation had the lowest survival curve. Interestingly, our group reported another distinct methylation profile of Bax, which was called $\operatorname{Bax} \Psi$ and this methylation profile correlated with an extended survival curve in glioma patients [20]. Bax $\Psi$ isoform was induced by methylation within intron 1 of the gene and induced the expression of a truncated form of $\mathrm{Bax}\left(\mathrm{Bax}^{\mathrm{p} 18}\right)$, which was more apoptogenic than $\mathrm{Bax}^{\mathrm{p} 21}$ (Figure 2C). Both intron 1 and exon 1 methylations were observed in non expressing Bax cells, suggesting that $\operatorname{Bax} \Psi$ profile might be an intermediary step in Bax silencing.

\subsection{2. $\mathrm{Bcl} 2$}

Surprisingly, a frequent hypermethylation of two $\mathrm{CpG}$ in the $\mathrm{Bcl} 2$ promoter was observed in prostate cancer and was associated with a decrease in Bcl2 expression [110]. The implication of $B c l 2$ methylation in prostatic cancer is not understood and has to be balanced by the additional decrease expression of pro-apoptotic protein such as Bak and Bik in these cancers. In glioma patients, $B c l 2$ methylation correlated both with global DNA methylation as well as another methylation of the antiapoptotic gene $B c l X L$, suggesting common methylation mechanisms and this was associated with an increase in intra tumor apoptosis [34].

\subsubsection{BH3-only}

BH3-only genes encode for pro-apoptotic proteins capable of sequestering anti-apoptotic proteins such as Bcl2 or BclXL (Figure 1). Several BH3-only genes are methylated in cancers. A decrease in HRK (Harakiri) expression was found in different cancers including prostate or glioma cancers and was associated with apoptosis resistance. HRK gene inactivation frequently resulted from a combination of an initial loss of one allele and a further methylation of the second allele [111]. Surprisingly, $H R K$ methylation was significantly higher in gastric tumor or glioma patients presenting WT p53 suggesting a role of this protein in the specific methylation of this gene. Literature suggests that $H R K$ methylation is not always correlated to a decrease in $H R K$ expression. Indeed, some large regions, which are very frequently methylated, seem to be those which are the least associated with silencing, while a dense methylation of few $\mathrm{CpG}$ closed to transcriptional initiation site abrogated $H R K$ expression [66]. Finally, deacetylation of $\mathrm{H} 3$ and $\mathrm{H} 4$ also regulate $H R K$ silencing. Specific methylation of Puma gene have been reported and associated to gene silencing in lymphoma while BIM was methylated in CML [11,32,33]. BIK inactivation in a mutational manner is observed in lymphomas, but epigenetic modification seems to be also implicated in $B I K$ silencing in other cancers as Multiple 
Myeloma [27]. BIK is methylated in glioma and in several cell lines but studies on a direct link between methylation and low expression is still under discussion. Nevertheless, inhibitors of DNA methylation in RCC cell lines induces a strong increase in BIK expression and abrogated apoptosis resistance. A synergic increase in both $\mathrm{mRNA}$ and BIK protein in HCC cells was observed following treatment with both inhibitors of Dnmt and HDAC suggesting a cooperation between deacetylation and DNA methylation occurs in BIK silencing [24,112].

\subsubsection{BCL2L10}

BCL2L10 belongs to the Bcl2 family but some conflicting results described this protein as pro or antiapoptotic. Yet, Xu et al. [21] reported that three sites where hypermethylated and three additional sites were partially methylated in BCL2L10 promoter in gastric tumor tissue and correlated with a decrease in the corresponding protein. Moreover, silencing of the gene was correlated to an increasing tumor size in these patients.

\subsubsection{APAF-1 (Apoptotic Protease-Activating Factor 1)}

APAF-1 silencing is frequently observed in melanomas and is partly due to LOH. As 5-aza treatment dramatically increased APAF-1 expression in methylated melanoma or leukemia cells but not in bladder cells, the link between APAF-1 methylation and gene silencing is not clear and might be tissue-dependent [18]. $A P A F-1$ methylation correlated with tumor grade in bladder cancers, RCC or neuroblastoma, but while a significant increase of $A P A F-1$ methylation was also observed in testicular germ cells tumors, the relative abundant basal $A P A F-1$ methylation in non tumoral tissue leads to a difficult interpretation of its role in tumorigenesis [16,85,113]. Since no correlation between $A P A F-1$ mRNA and APAF-1 protein content could be found, post-translational modification of APAF-1 are suspected to be dramatically involved in apoptosis sensitivity [114]. However, inhbition of $A P A F-1$ methylation by 5 -aza deoxycytidine, restores the Apoptosome formation and the activation of Casp 9. On one hand, specific methylation of $\mathrm{CpG}$ were found in a region from +87 to +128 in leukemia and not in normal cells, and on the other hand, no modification in the methylation rate in CGI $(-680+420)$ of the gene could be found between melanomas and normal cells, leading to the idea that methylation of an enhancer, still unknown until now, could also be implicated in the phenomenon [17]. Finally, an increase in Dnmt1 content is suspected to favor $A P A F-1$ methylation whose complete silencing probably requires the recruitment of the additional corepressors HDAC1 and MBD2.

\subsubsection{Inhibitor Apoptis Proteins (IAPs)}

Inhibitor Apoptosis Protein (IAP) is composed of eight members presenting from one to three BIR domain from the baculovirus. IAPs antagonized effectors caspases : Casp 3, Casp 7 and Casp 9, and inhibit apoptosis. A loss of methylation in these promoters might be related to apoptosis resistance. Five IAP promoters (ciAP1, ciAP2, Survivin, NAIP and XIAP) were hypomethylated in oral tumors and a strong correlation of expression between each other suggests some common regulatory mechanisms. However, any correlation between IAP expression and malignant transformation in oral tumors was found, suggesting that a gain in expression of IAP genes might only partially contribute to 
tumorigenesis and not be at its origin [115]. Survivin is normally expressed during embryogenesis and shut down in adult differentiated tissues. Strikingly, Survivin hypomethylation and high overexpression of the protein has been found in different cancers including ovarian, HCC(Hepato Cellular Carcinoma) and glioma. A correlation between Dnmt1 level and Survivin methylation status suggest that Dnmt1 is required for Survivin regulation. Esteve et al. [116] proposed that Survivin silencing was mediated by a heterotrimer SP1/Dnmt1/p53 complex initiated by TFs/Dnmts interactions and specific recruitment of Dnmt1 on TF-Boxes.

\subsubsection{BNIP3}

The TSG, BNIP3 (Bcl2/adenovirus E1B 19KDa interacting protein 3) is normally activated by HIF (hypoxia inducible factor) in response to hypoxia and can promote apoptosis. As chronic hypoxia is a hallmark of environment of many solids tumors, cancers have frequently developed strategies of resistance, and among them, the monoallelic deletion of BNIP3. Indeed, $\mathrm{CpG}$ islands were found from the $5^{\prime}$ end to the intron $2(-1162 /+538)$ of BNIP3 gene and methylation in these sites correlated with low expression of BNIP3 in pancreatic tumors where most of the $\mathrm{CpG}$ analyzed were specifically methylated in tumoral tissue [117]. Silencing of the gene could be explained by the presence of 4 SP1 motifs in the methylated region and methylation in the vicinity of HRE binding site in pancreatic tumors. Relationships between inactivation of BNIP3 gene and survival is confusing. However, forced expression of BNIP3 in pancreatic tumoral cell lines leads to apoptosis. Survival time of patients with BNIP3 methylation was shorter than in absence of methylation in gastric tumors, whereas no such association could be found in breast tumors [28]. In addition, patients with methylation exhibited resistance to chemotherapy compared to patients with no methylation, suggesting that methylation of BNIP3 is a predictive factor in the prognosis and response to treatment in colorectal cancer patients [118-120].

\subsubsection{XAF-1}

The pro-apoptotic protein XAF-1 (XIAP-associated Factor 1) is the main inhibitor of XIAP by inducing its sequestration (Figure 1). No canonical CGI could be found in promoter but two shorts regions (I and II) quite rich in CpG were found within -1867/-343 area but methylation in both I and II appeared not critical for XAF-1 expression in gastric cancers [99]. These authors demonstrated that XAF-1 expression was rather tightly controlled by the methylation status of seven independent CpG localized in the proximity of the transcriptional initial start site (-234/-23). Common and additional methylated sites in -164 to 109 were found in colon carcinoma cell lines suggesting tissue-specific mechanisms of inhibition particularly the two $\mathrm{CpG}$ located to the transcriptional start site [121]. Indeed, similar results from Lee et al. reported that $X A F-1$ hypermethylation of total or partial $14 \mathrm{CpG}$ loci from -20 to -695 of the promoter, was associated to a decrease in XAF-1 expression and is correlated with disease progression, in particular malignancy in bladder cancers [122].

\subsubsection{Death Associate Protein Kinase (DAPK)}

Death associated protein kinase (DAPK) gene encodes for a $\mathrm{Ca}+/$ calmodulin-regulated Ser/Thr kinase including a death domain and is involved in both intrinsic and extrinsic apoptosis. DAPK 
promoter is the most frequently apoptosis-related gene aberrantly methylated in cancers at frequencies often from $70-90 \%$. Methylation of $D A P K$ promoter is clearly associated to disease in many cancers. As some examples, patients with $D A P K$ methylation in gastric cancers present a response rate significantly lower than patients without methylation and $D A P K$ methylation also correlated with grade in testicular tumors, recurrence in bladder tumors, or invasion and metastasis in lung cancers $[93,98,123]$. Conversely, any influence of $D A P K$ methylation could be found on prognosis in malignant mesothelioma as neither CXCA patients and overexpression of DAPK increased the radiosensitivity of SiHa cells [42,46]. As methylation correlated to low DAPK expression, Mittag et al. [51] suggested that methylation of $D A P K$ conferring apoptosis resistance was an early event in tumorigenesis and several molecular explanations have been proposed. DAPK gene present a CGI extending $2500 \mathrm{pb}$ from the transcriptional start site. A high heterogeneity of methylation of $\mathrm{CpG}$ was found in lung cancers suggesting that some $\mathrm{CpG}$ are more particularly associated with gene silencing than others. Methylation in the intron 1 partially correlated to DAPK expression while those included in 5' flanking region are more related to DAPK silencing [53]. In cancer cells, edge of CGI is more sensible to methylation than the center but is not associated to gene expression regulation [124]. It has been hypothesized that initial methylation of edge of CGI, particularly in a repetitive element, such as Alu sequences, could bring a functional anchorage of methylation machinery for further methylation toward the center of the CGI which would affect gene expression. Indeed, a frequent methylation in the exon 2 of cancer cells was not correlated to low expression. Pulling et al. [125] also recently revealed two methylation hot spots containing each 8-10 CpG whose methylation abolished DAPK expression. Methylation occurring in the vicinity of CP2 or FOXA2 binding sites negatively controlled the expression of the two promoters of DAPK. Concomitantly to DNA methylation, deacetylation of histones $\mathrm{H} 3$ and $\mathrm{H} 4$ was observed suggesting a complex including Dnmt and HDAC in DAPK silencing [124]. A role of DAXX on DNA hypermethylation has recently emerged. DAXX is a dual protein: i) implicated in apoptosis and ii) is a transcriptional regulator able to bind to HDAC and Dnmt to repress gene transcription. DAXX can not directly bind to DNA and Puto et al. [126] demonstrate that its repression activity was mediated via RelB interaction (Figure 2B). Formation of the ternary DAXX/Dnmt1/RelB complex transformed the transcriptional activity of RelB into a repressor complex by inducing a targeted methylation-mediated silencing on RelB-binding sequences in several genes including $D A P K$. Participation of chromatin remodeling enzymes was confirmed by the co-recuitment of HDAC2 on DAXX.

\subsubsection{Ras Association Doman Family 1A (RASSF1A)}

Ras association domain family 1A (K-Ras/ RASSF1A) complex can activate Bax via an additional intermediately interaction with MOAP-1. In spite of absence of TATA box (also called Goldberg-Hogness box), methylation in CGI adjacent to the transcription initiation site induced gene silencing and RASSF1A methylation was considered has a good prognosis marker in breast, CRCC and some lungs cancers [127]. Some results in other cancers are less convincing, such as the absence of a correlation between methylation and clinical parameters or the observation that while RASSIFA is methylated at $48-60 \%$ in bladder cancers, a strong methylation (42\%) was also found in normal corresponding tissue [128,129]. Interestingly, recent reports brought uncommon molecular mechanisms in RASSF1A 
methylation. Tian et al. [77] demonstrated that p53 was recruited on the p53 binding site located in distal promoter specifically in testis tumors but not in normal tissue and correlaled to DNA methylation in the proximal promoter (Figure 2A). A first recruitment of the HDAC1/SETDB1 (a histone methyltransferase) complex was supposed to initiate epigenetic marks on $R A S S F 1 A$ promoter. Secondly, RASSF1A methylation was achieved by the following recruitment of Dnmt3a favored by direct binding with both HDAC1 and SETBD1 [130]. Moreover, the $\triangle \mathrm{Dnmt} 3 \mathrm{~b} 4$ isoform of Dnmt3b lacking exon 6, appeared essential for RASSF1A silencing in a methylation manner in lung cancer, demonstrating for the first time the role of Dnmt isoforms in dn methylation in cancer cells [131].

Figure 2. Mechanisms of DNA hypermethylation and apoptosis-related genes inactivation (a) Inactivation of RASSF1A by Dnmt/P53 cooperation. (b) Inactivation of DAPK by the ternary complex Dnmt/RelB/DAXX. (c) Specific methylation of $B A X$ leading to BAX $\psi$ or BAX silencing.

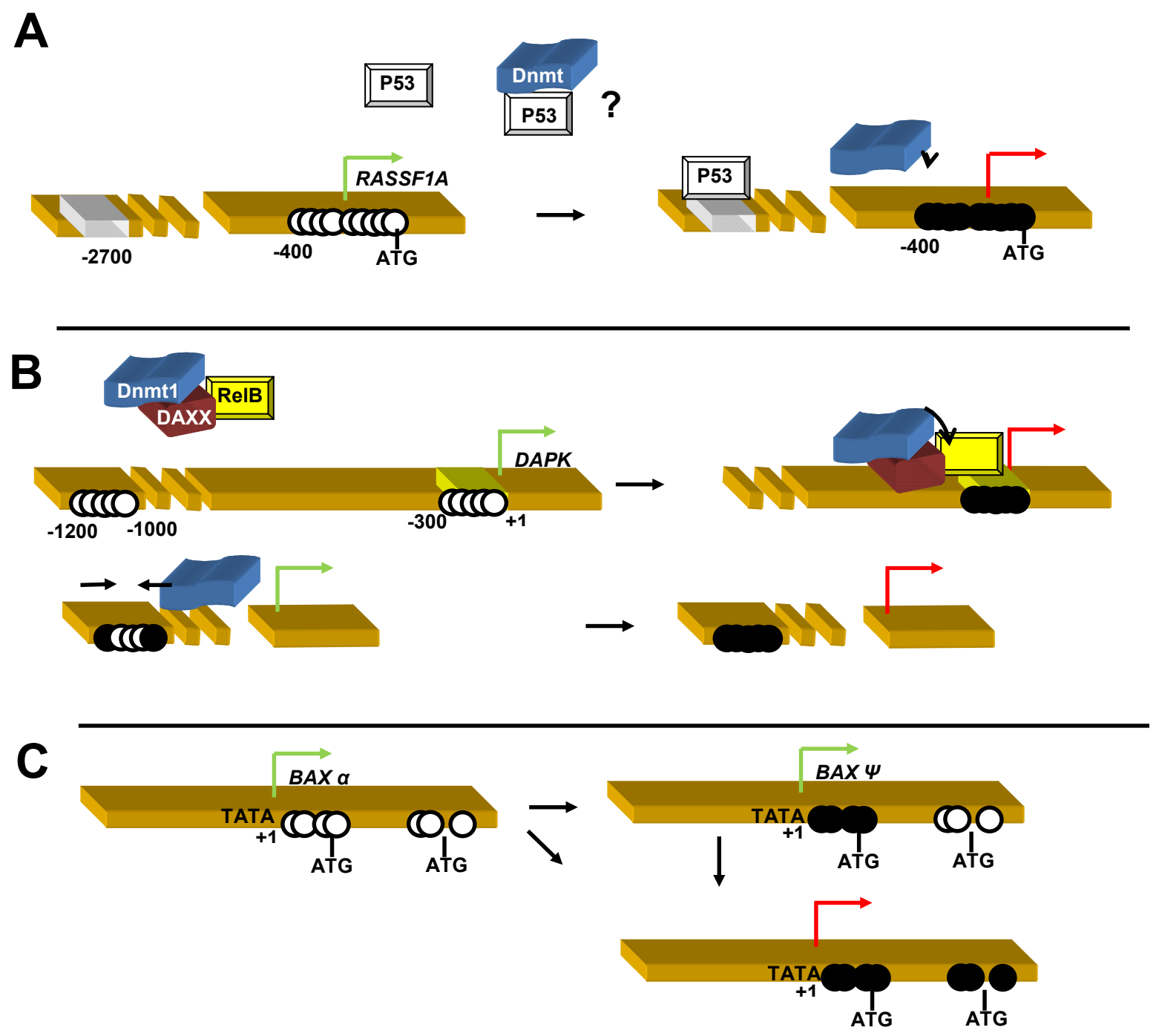

\subsubsection{Secreted Apoptos-Related Protein 2 (SARP2)}

Secreted Apoptosis-Related Protein (SARP) families are considered to counteract the oncogenic Wnt signaling pathway, and inactivation of this gene may aid cancer development and progression. 
SARP proteins, also named sFRP (for Secreted Frizzled-Related Protein), exert differential effects on osteoblastic differentiation of mouse mesenchymal cells and cellular apoptosis of mouse osteoblasts in vitro [132]. SARP2 methylation has been reported in several cancers such as pancreatic tumors with very high frequencies. SARP2 methylation may occur in the steps of pancreatic tumorigenesis as SARP2 methylation was observed in both begnin and malignant tumors and no statistical link could be found between SARP2 methylation and disease progression [84].

\subsubsection{Interferon Regulatory Factor 8 (IRF8)}

Interferon regulatory factor 8 (IRF8) is an apoptosis-regulating gene that has been demonstrated to directly regulate Bax transcription in vivo [133]. IRF8 is hypermethylated in different types of cancer and is an essential regulator in Fas-mediated apoptosis pathway. Moreover, IRF8 is a metastasis suppressor in solid tumors and metastatic tumor cells use DNA hypermethylation to repress IRF8 expression to evade apoptotic cell death and to acquire a metastatic phenotype in human colon carcinoma [134]. IRF8 was also identified as a functional tumor suppressor, which is frequently silenced by epigenetic mechanism in multiple carcinomas [135]. Finally, silencing of IRF8 expression, by DNA methylation or other epigenetic mechanisms, may be associated with the malignant phenotype of Multiple Myeloma [136].

\section{Significance of Methylation in Cancers}

As seen above, mechanisms governing de novo methylation in apoptosis related genes are poorly understood and often completely unknown. A significant decrease in Dnmt3a content has been recently reported during TRAIL-induced apoptosis in rat hepatic cells [137]. It was generally believed that promoters with low $\mathrm{CpG}$ content were easily methylated but that they did not severely affect gene transcription. Similar hypotheses were proposed for a low percentage of methylation in high CpG regions. Nevertheless, in regards to increasing knowledge of DNA methylation mechanisms, reality may be much more complicated. Methylation of one site in $300 \mathrm{pb}$ in several promoters could be efficient to repress transcription. In some cases, specificity of Dnmt has been proposed, as the requirement of Dnmt3b or Dnmt1 for promoter methylation of TMS1 or Survivin, respectively. Some recent works converging from several laboratories have demonstrated the existence of targeted methylation via Dnmts/TF interactions. The TF PU.1 physically interacts with Dnmt3a and mediated gene silencing via PU.1-binding sites in the promoters [55]. Similar observations with Dnmts/TF interactions have been described for $\mathrm{p} 53$ and cMyc [138,139]. 5-aza-deoxycitidine activates p53 signaling pathway and apoptosis cells [140]. As p53 is (i) a key regulator of apoptosis and (ii) control the transcription of many apoptosis related-genes, silencing via methylation of p53 binding sites by the Dnmt3a/p53 complex may confer a signature participating in apoptosis resistance. We demonstrated that TF-mediated targeted methylation could be a frequent phenomenon as Dnmt1, 3a and $3 \mathrm{~b}$ potentially interacts with a large panel of TFs in vitro [141,142]. Methylation of SP1-binding sites has been reported in silencing of beclin. We recently validated Dnmt1/SP1 or Dnmt3/SP1 interactions. Modulation of theses complexes in tumoral cells could contribute to de novo methylation in apoptosis related genes promoters. Moreover, different Dnmt1/TFs complexes are observed in the different phases of a cell cycle, which means that targeted DNA methylation may be dependent on the 
accessibility of each TF [143]. EZH2 has been implicated in DAPK silencing. An increase of EZH2 expression in prostate and glioma cancers compared to normal tissue and a strong correlation between EZH2 level and bladder cancer stages may suggest that Polycomb group could partially control gene silencing observed in these tumors $[15,70,144]$. An illustration of this mechanism was the EZH2mediated silencing of hDAB2IP, a GTPase-activating protein modulating apoptosis in prostate tumors. As APAF-1 expression is regulated by E2F1, SP1 and p53, further studies on possible mechanisms of targeted methylation and stabilization and kinetics of Dnmt/E2F1, Dnmt/SP1 or/and Dnmt/SP1 complexes may lead to understand the APAF-1 silencing in tumors.

We have seen above that numerous genes implicated in apoptosis could be aberrantly methylated in cancers and this was often associated to apoptosis resistance. Netherveless, hypermethylation of proapoptotic genes may not always associated with survival curve differences or grade. In $\mathrm{CxCa}$ (Cervical cancer), correlation of methylation have been found between Fas and DAPK in one hand and TRAILR1 and Fas in another hand [63]. Authors suggested that high apoptosis resistance in tumor cells could resulted from the silencing of several apoptosis related genes issued from common or different mechanisms. Similarly, combined methylation of TMS1 and DAPK in gastric cancers was associated to patients with a shorter survival curve in comparison to patients with only one methylation or no methylation [47]. Our recent work agree with these observations [34]: among eight genes related to the apoptotic program, only methylation status of Bax correlated to survival curve. As all these genes are included in a global cascade, we proposed that in glioma patients, each methylation could contribute to a small part in apoptosis resistance. A value of +1 was attributed to each tumor harboring a methylation in a gene coding a pro-apoptotic protein and -1 was attributed to each tumor harboring an unmethylation of an anti-apoptotic gene. Glioma patients scores revealed a strong correlation between score and apoptosis level and moreover, patients with the lowest score presented a significantly shorter survival curve. Similar clusters of gene methylation demonstrated a shorter survival in mesothelioma patients with combined methylation of $D A P K, R A S S A F 1 A$ and $R A R \beta$ while no association was found for each methylation independently. Moreover, clustering of patients with three hypermethylated genes compared to unmethylated genes or one hypermethylated gene severly decrease the survival in neublastoma patients [85].

Recently, microRNAs (miRNAs) have been implicated in regulation of gene expression and of apoptosis-related gene expression. MiRNAs are small noncoding RNAs that function as endogenous post-transcriptional silencers of target genes. MiRNAs are expressed in a tissue specific manner and play important roles in cell proliferation, apoptosis and differentiation. Some miRNAs promoters are controlled by epigenetic alterations such as DNA methylation [145]. Anti-apoptotic genes BCL2L2 and E2F6 are targets of miR-205 and miR-31, respectively. By downregulating Bcl-w and E2F6, miR-205 and miR-31 promote chemotherapeutic agents-induced apoptosis in prostate cancer cells. The promoter region of the miR-205 gene was found to be hypermethylated in cell lines derived from advanced prostate cancers, contributing to the downregulation of the gene [146]. Moreover, miR-214 promoter is regulated by DNA methylation and reduces cell survival, induces apoptosis and enhances sensitivity to cisplatin through directly inhibiting Bcl212 expression in cervical cancer cells [147]. In many tumor types the promoters of the miR-34a and the miR-34b/c genes are subject to inactivation by CpG methylation. MiR-34a is commonly deleted in neuroblastomas. Furthermore, the loss of miR-34 
expression has been linked to resistance against apoptosis induced by p53 activating agents used in chemotherapy [148].

\section{Therapeutical Strategies}

As seen above, methylation of several genes are associated with disease progression, survival, tumoral grade or metastasis and detection of these aberrant methylation in apoptosis genes could be used as markers of disease and constitute potential markers of prognosis in patients. Detection of such aberrant DNA methylation could be made in serum patients as illustrated in gastric cancers or in urine for bladder cancer patients [15,47,55,63,70,77,84,128-149]. Systematic research of methylation markers of disease in serum or urine might constitute a new non invasive approach for efficient detection and prognosis of cancer in the future.

Chemical agents targeting methylation machinery demonstrated positive effects against apoptosis resistance in both in vitro and in vivo studies. These interesting results lead to their proposal for clinical studies in cancer treatments. Natural compounds like green tea polyphenols such as EGCG have the potential to affect multiple biological pathways, including gene expression, growth factor-mediated pathways, the mitogen-activated protein kinase-dependent pathway, and the ubiquitin/proteasome degradation pathway [150]. The effects of dietary polyphenols such as EGCG on DNMTs appear to have their direct inhibition by interaction with the catalytic site of the DNMT1 molecule, and may also influence methylation status indirectly through metabolic effects associated with energy metabolism [151]. These bioactive components are able to modulate epigenetic events, and their epigenetic targets are known to be associated with breast cancer prevention and therapy [152,153]. Therapeutic activity of hypomethylating agents such as decitabine (DAC, Dacogen ${ }^{\text {TM}}$; MGI Pharma, Inc.) and 5-azacytidine (AZA, Vidaza ${ }^{\mathrm{TM}}$; Celgene Corp.) have been used in clinical approaches in patients with myelodisplasic syndromes (MDS). Phase III clinical trials gave $60 \%$ of response in the arm treated with 5 -aza and among them $7 \%$ of patients obtained a complete remission. Survival was increased from 14 months to 20 months. Similar studies were realized with decitabine, which gave a $17 \%$ response in a large phase III study. Global DNA hypomethylation induced by 5-azacytidine is progressive and related to cell cycle status [154]. Cells with large hypomethylation underwent apoptosis while cells without DNA hypomethylation were still alive. Several in vitro studies in different cancer cell lines demonstrated an efficient demethylation-dependent increase of pro-apoptotic proteins like DAPK and Bcl2L10 [22]. In vitro and in vivo studies in rodents demonstrated positive effects on combined decitabine and TRAIL death inducer on apoptosis sensibility of glioma cell lines mediated by both TRAILR1 and caspase- 8 reexpression in a demethylation manner [155]. Moreover, a large portion of tumor-infiltrating $\mathrm{CD} 8(+) \mathrm{T}$ cells are $\mathrm{FasL}(+)$, and a critical role for FasL in decitabine and vorinostat-mediated tumor suppression in vivo is suggested. These data imply that combined modalities of chemotherapy to sensitize the tumor cell to Fas-mediated apoptosis and CTL immunotherapy is an effective approach for the suppression of colon cancer metastasis [156]. On the other hand, global DNA methylation and local hypomethylation in oncogenes or genes favoring apoptosis resistance argue in the addition of lipotropes (methionine, choline, folate, VitB12) as methyl donors to both prevent and limit aggressiveness. Treatment of glioma cells with folate reduced global hypomethylation, proliferation index and increased apoptosis sensitivity [157]. Similar results were 
observed in breast cancer cell lines [158]. Moreover, a delay in occurrence and a decrease in tumor size was observed in glioma chemo-induced rats treated with folate compared to normal diet [159]. Several mechanisms could explain these results. Invalidation of Dnmt1 has been associated to global DNA methylation, chromosal instability and lymphomas [160]. As a partial cooperation between de novo and maintaining Dnmts have also been reported increasing methyl donors accessibility may palliate mMase defects in cancers mainly promoted by Dnmt1/PCNA/URHF1 disruption and limit further chromosomal instability and local hypomethylations. Increasing dnMase activity is also supported by an increase in both Dnmt3a and 3b genes expression in glioma cells treated with folate in response to detachment of SP1 in favor of SP3 in these promoters.

\section{Conclusions}

Recent findings on targeted DNA methylation open new perspectives for therapeutical studies. Implication of c-Myc, p53 and SP1 in aberrant methylation of gene coding for pro-apoptotic proteins has to be more investigated. Systematic analysis of potential TF/Dnmt interaction revealed by in vitro studies may also reveal new specific interactions implicated in apoptosis resistance in cancer cells. By blocking these interactions, we could imagine both restore a specific demethylation of selective genes in cancer cells and apoptosis sensibility. This strategy would conturn significant side-effects currently produced by unspecific drugs like demethyl agents. While 5-aza treatment reduced apoptosis resistance in several cancer cell lines, prolonged exposition is associated with global DNA hypomethylation and activation of invasiveness pathway genes like UVA both in vitro and in vivo [161]. Combinations of existing therapies towards proliferative cells and specific reactivation of apoptosis sensitivity would constitue new therapies being more adapted to each patient in the future (Figure 3).

Figure 3. DNA methylation and anti-apoptotic strategies (a) Effects of both DNA demethylating agents and pro-methylation, mediated by folate, on apoptosis-related genes and apoptosis. (b) Conflicting results of demethylated agents and specific strategies against targeted DNA methylation on apoptosis.

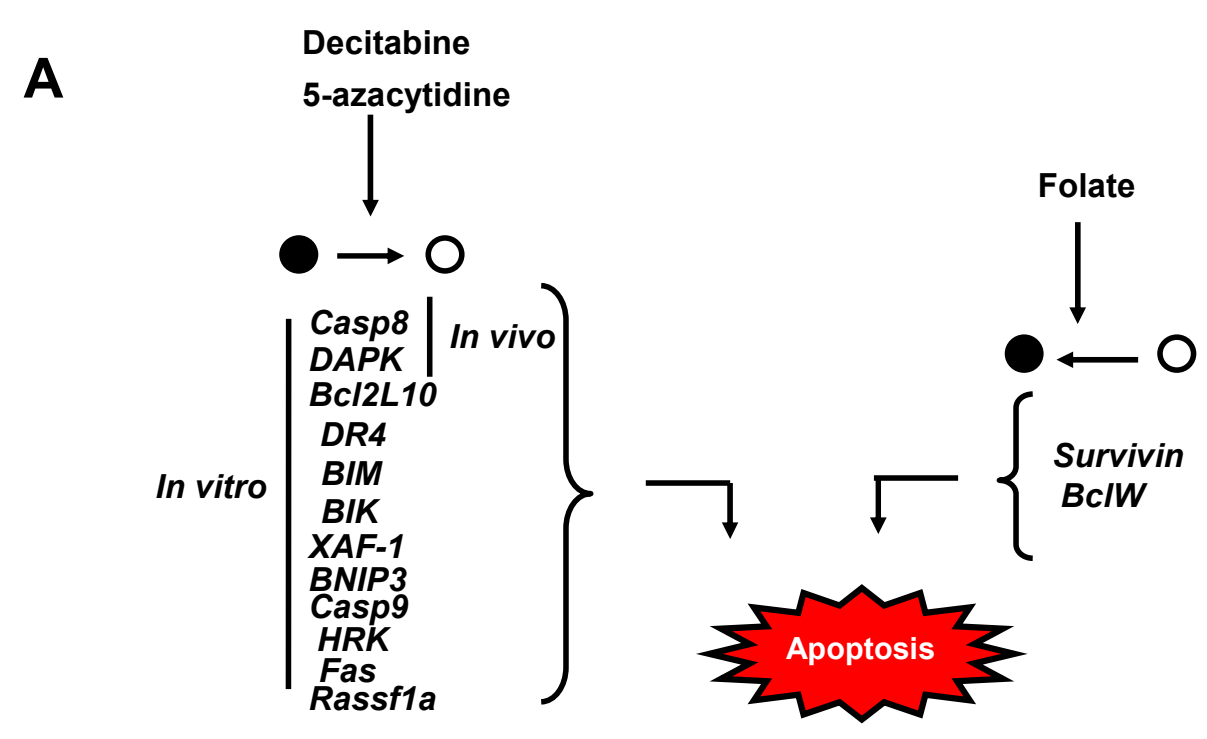


Figure 3. Cont.

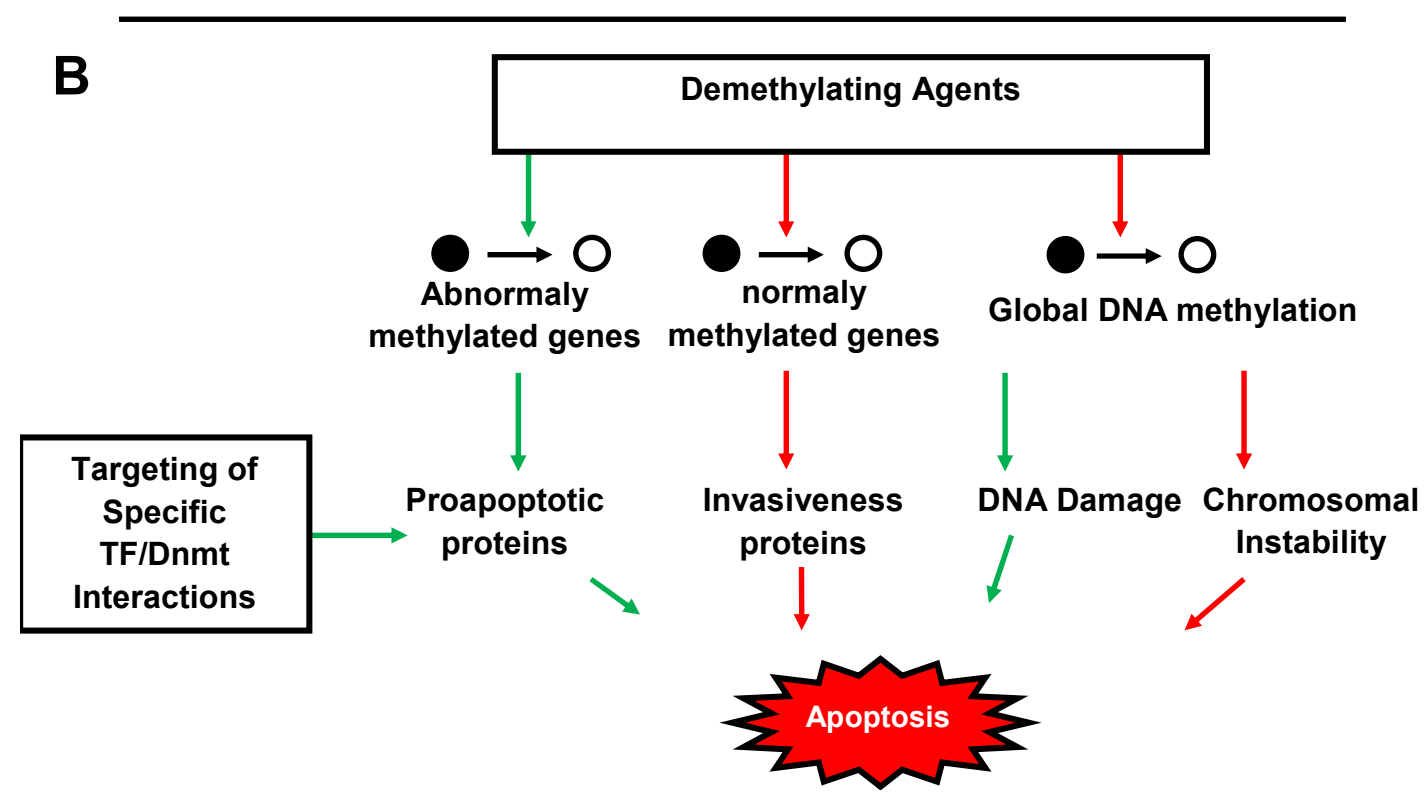

\section{Acknowledgments}

We thank the University of Franche-Comté, the University of Nantes, the Ministère de l'Enseignement Supérieur et de la Recherche (MESR) and the Cancéropôle Grand Ouest/Région Pays de la Loire.

\section{Conflict of Interest}

The authors declare no conflict of interest.

\section{References}

1. Kuribara, R.; Honda, H.; Matsui, H.; Shinjyo, T.; Inukai, T.; Sugita, K.; Nakazawa, S.; Hirai, H.; Ozawa, K.; Inaba, T. Roles of Bim in apoptosis of normal and Bcr-Abl-expressing hematopoietic progenitors. Mol. Cell. Biol. 2004, 24, 6172-6183.

2. Hanahan, D.; Weinberg, R.A. The hallmarks of cancer. Cell 2000, 100, 57-70.

3. Bird, A. DNA methylation patterns and epigenetic memory. Genes Dev 2002, 16, 6-21.

4. Chen, T.; Ueda, Y.; Dodge, J.E.; Wang, Z.; Li, E. Establishment and maintenance of genomic methylation patterns in mouse embryonic stem cells by Dnmt3a and Dnmt3b. Mol. Cell. Biol. 2003, 23, 5594-5605.

5. Gama-Sosa, M.A.; Slagel, V.A.; Trewyn, R.W.; Oxenhandler, R.; Kuo, K.C.; Gehrke, C.W.; Ehrlich, M. The 5-methylcytosine content of DNA from human tumors. Nucleic Acids Res. 1983, $11,6883-6894$.

6. Feinberg, A.P.; Vogelstein, B. Hypomethylation distinguishes genes of some human cancers from their normal counterparts. Nature 1983, 301, 89-92.

7. Esteller, M. Epigenetics in cancer. N. Engl. J. Med. 2008, 358, 1148-1159.

8. Hoffmann, M.J.; Schulz, W.A. Causes and consequences of DNA hypomethylation in human cancer. Biochem. Cell. Biol. 2005, 83, 296-321. 
9. Ehrlich, M.; Woods, C.B.; Yu, M.C.; Dubeau, L.; Yang, F.; Campan, M.; Weisenberger, D.J.; Long, T.; Youn, B.; Fiala, E.S.; et al. Quantitative analysis of associations between DNA hypermethylation, hypomethylation, and DNMT RNA levels in ovarian tumors. Oncogene 2006, 25, 2636-2645.

10. Ehrlich, M. DNA hypomethylation in cancer cells. Epigenomics 2009, 1, 239-259.

11. Hatziapostolou, M.; Iliopoulos, D. Epigenetic aberrations during oncogenesis. Cell. Mol. Life Sci. 2011, 68, 1681-1702.

12. Garrison, S.P.; Jeffers, J.R.; Yang, C.; Nilsson, J.A.; Hall, M.A.; Rehg, J.E.; Yue, W.; Yu, J.; Zhang, L.; Onciu, M.; et al. Selection against PUMA gene expression in Myc-driven B-cell lymphomagenesis. Mol. Cell. Biol. 2008, 28, 5391-5402.

13. Saldana-Meyer, R.; Recillas-Targa, F. Transcriptional and epigenetic regulation of the p53 tumor suppressor gene. Epigenetics 2011, 6, 1068-1077.

14. Christoph, F.; Hinz, S.; Weikert, S.; Kempkensteffen, C.; Schostak, M.; Miller, K.; Schrader, M. Comparative promoter methylation analysis of p53 target genes in urogenital cancers. Urol. Int. 2008, 80, 398-404.

15. Hinz, S.; Kempkensteffen, C.; Weikert, S.; Schostak, M.; Schrader, M.; Miller, K.; Christoph, F. EZH2 polycomb transcriptional repressor expression correlates with methylation of the APAF-1 gene in superficial transitional cell carcinoma of the bladder. Tumour Biol. 2007, 28, 151-157.

16. Christoph, F.; Kempkensteffen, C.; Weikert, S.; Kollermann, J.; Krause, H.; Miller, K.; Schostak, M.; Schrader, M. Methylation of tumour suppressor genes APAF-1 and DAPK-1 and in vitro effects of demethylating agents in bladder and kidney cancer. Br. J. Cancer. 2006, 95, 1701-1707.

17. Furukawa, Y.; Sutheesophon, K.; Wada, T.; Nishimura, M.; Saito, Y.; Ishii, H. Methylation silencing of the Apaf-1 gene in acute leukemia. Mol. Cancer Res. 2005, 3, 325-334.

18. Soengas, M.S.; Capodieci, P.; Polsky, D.; Mora, J.; Esteller, M.; Opitz-Araya, X.; McCombie, R.; Herman, J.G.; Gerald, W.L.; Lazebnik, Y.A.; et al. Inactivation of the apoptosis effector Apaf-1 in malignant melanoma. Nature 2001, 409, 207-211.

19. Pompeia, C.; Hodge, D.R.; Plass, C.; Wu, Y.Z.; Marquez, V.E.; Kelley, J.A.; Farrar, W.L. Microarray analysis of epigenetic silencing of gene expression in the KAS-6/1 multiple myeloma cell line. Cancer Res. 2004, 64, 3465-3473.

20. Cartron, P.F.; Oliver, L.; Martin, S.; Moreau, C.; LeCabellec, M.T.; Jezequel, P.; Meflah, K.; Vallette, F.M. The expression of a new variant of the pro-apoptotic molecule Bax, Baxpsi, is correlated with an increased survival of glioblastoma multiforme patients. Hum. Mol. Genet. 2002, 11, 675-687.

21. Xu, J.D.; Cao, X.X.; Long, Z.W.; Liu, X.P.; Furuya, T.; Xu, J.W.; Liu, X.L.; De Xu, Z.; Sasaki, K.; Li, Q.Q. BCL2L10 protein regulates apoptosis/proliferation through differential pathways in gastric cancer cells. J. Pathol. 2011, 223, 400-409.

22. Fabiani, E.; Leone, G.; Giachelia, M.; D'Alo, F.; Greco, M.; Criscuolo, M.; Guidi, F.; Rutella, S.; Hohaus, S.; Voso, M.T. Analysis of genome-wide methylation and gene expression induced by 5-aza-2'-deoxycytidine identifies BCL2L10 as a frequent methylation target in acute myeloid leukemia. Leuk. Lymphoma 2010, 51, 2275-2284. 
23. San Jose-Eneriz, E.; Agirre, X.; Jimenez-Velasco, A.; Cordeu, L.; Martin, V.; Arqueros, V.; Garate, L.; Fresquet, V.; Cervantes, F.; Martinez-Climent, J.A.; et al. Epigenetic down-regulation of BIM expression is associated with reduced optimal responses to imatinib treatment in chronic myeloid leukaemia. Eur. J. Cancer. 2009, 45, 1877-1889.

24. Kim, T.Y.; Zhong, S.; Fields, C.R.; Kim, J.H.; Robertson, K.D. Epigenomic profiling reveals novel and frequent targets of aberrant DNA methylation-mediated silencing in malignant glioma. Cancer Res. 2006, 66, 7490-7501.

25. Sturm, I.; Stephan, C.; Gillissen, B.; Siebert, R.; Janz, M.; Radetzki, S.; Jung, K.; Loening, S.; Dorken, B.; Daniel, P.T. Loss of the tissue-specific proapoptotic BH3-only protein Nbk/Bik is a unifying feature of renal cell carcinoma. Cell Death Differ. 2006, 13, 619-627.

26. Murphy, T.M.; Sullivan, L.; Lane, C.; O'Connor, L.; Barrett, C.; Hollywood, D.; Lynch, T.; Lawler, M.; Perry, A.S. In silico analysis and DHPLC screening strategy identifies novel apoptotic gene targets of aberrant promoter hypermethylation in prostate cancer. Prostate 2011, $71,1-17$.

27. Hatzimichael, E.; Dasoula, A.; Kounnis, V.; Benetatos, L.; Lo Nigro, C.; Lattanzio, L.; Papoudou-Bai, A.; Dranitsaris, G.; Briasoulis, E.; Crook, T. Bcl2-interacting killer CpG methylation in multiple myeloma: a potential predictor of relapsed/refractory disease with therapeutic implications. Leuk. Lymphoma. 2012, 53, 1709-1713.

28. Sugita, H.; Iida, S.; Inokuchi, M.; Kato, K.; Ishiguro, M.; Ishikawa, T.; Takagi, Y.; Enjoji, M.; Yamada, H.; Uetake, H.; et al. Methylation of BNIP3 and DAPK indicates lower response to chemotherapy and poor prognosis in gastric cancer. Oncol. Rep. 2011, 25, 513-518.

29. Hiraki, M.; Kitajima, Y.; Nakafusa, Y.; Nakamura, J.; Hashiguchi, K.; Sumi, K.; Noshiro, H.; Miyazaki, K. CpG island methylation of BNIP3 predicts resistance against S-1/CPT-11 combined therapy in colorectal cancer patients. Oncol. Rep. 2010, 23, 191-197.

30. Pike, B.L.; Greiner, T.C.; Wang, X.; Weisenburger, D.D.; Hsu, Y.H.; Renaud, G.; Wolfsberg, T.G.; Kim, M.; Weisenberger, D.J.; Siegmund, K.D.; et al. DNA methylation profiles in diffuse large B-cell lymphoma and their relationship to gene expression status. Leukemia 2008, 22, 1035-1043.

31. Calvisi, D.F.; Ladu, S.; Gorden, A.; Farina, M.; Lee, J.S.; Conner, E.A.; Schroeder, I.; Factor, V.M.; Thorgeirsson, S.S. Mechanistic and prognostic significance of aberrant methylation in the molecular pathogenesis of human hepatocellular carcinoma. J. Clin. Invest. 2007, 117, 2713-2722.

32. Michalowski, M.B.; de Fraipont, F.; Plantaz, D.; Michelland, S.; Combaret, V.; Favrot, M.C. Methylation of tumor-suppressor genes in neuroblastoma: The RASSF1A gene is almost always methylated in primary tumors. Pediatr. Blood Cancer 2008, 50, 29-32.

33. Cho, S.; Lee, J.H.; Cho, S.B.; Yoon, K.W.; Park, S.Y.; Lee, W.S.; Park, C.H.; Joo, Y.E.; Kim, H.S.; Choi, S.K.; et al. Epigenetic methylation and expression of caspase 8 and survivin in hepatocellular carcinoma. Pathol. Int. 2010, 60, 203-211.

34. Hervouet, E.; Vallette, F.M.; Cartron, P.F. Impact of the DNA methyltransferases expression on the methylation status of apoptosis-associated genes in glioblastoma multiforme. Cell Death Dis. 2010, 1, e8. 
35. Malekzadeh, K.; Sobti, R.C.; Nikbakht, M.; Shekari, M.; Hosseini, S.A.; Tamandani, D.K.; Singh, S.K. Methylation patterns of Rb1 and Casp-8 promoters and their impact on their expression in bladder cancer. Cancer Invest. 2009, 27, 70-80.

36. Bello, M.J.; De Campos, J.M.; Isla, A.; Casartelli, C.; Rey, J.A. Promoter CpG methylation of multiple genes in pituitary adenomas: frequent involvement of caspase-8. Oncol. Rep. 2006, 15, 443-448.

37. Margetts, C.D.; Astuti, D.; Gentle, D.C.; Cooper, W.N.; Cascon, A.; Catchpoole, D.; Robledo, M.; Neumann, H.P.; Latif, F.; Maher, E.R. Epigenetic analysis of HIC1, CASP8, FLIP, TSP1, DCR1, DCR2, DR4, DR5, KvDMR1, H19 and preferential 11p15.5 maternal-allele loss in von Hippel-Lindau and sporadic phaeochromocytomas. Endocr. Relat. Cancer 2005, 12, 161-172.

38. Gonzalez-Gomez, P.; Bello, M.J.; Inda, M.M.; Alonso, M.E.; Arjona, D.; Aminoso, C.; LopezMarin, I.; de Campos, J.M.; Sarasa, J.L.; Castresana, J.S.; et al. Deletion and aberrant CpG island methylation of Caspase 8 gene in medulloblastoma. Oncol. Rep. 2004, 12, 663-666.

39. Harada, K.; Toyooka, S.; Shivapurkar, N.; Maitra, A.; Reddy, J.L.; Matta, H.; Miyajima, K.; Timmons, C.F.; Tomlinson, G.E.; Mastrangelo, D.; et al. Deregulation of caspase 8 and 10 expression in pediatric tumors and cell lines. Cancer Res. 2002, 62, 5897-5901.

40. Shivapurkar, N.; Toyooka, S.; Eby, M.T.; Huang, C.X.; Sathyanarayana, U.G.; Cunningham, H.T.; Reddy, J.L.; Brambilla, E.; Takahashi, T.; Minna, J.D.; et al. Differential inactivation of caspase-8 in lung cancers. Cancer Biol. Ther. 2002, 1, 65-69.

41. Wu, Y.; Alvarez, M.; Slamon, D.J.; Koeffler, P.; Vadgama, J.V. Caspase 8 and maspin are downregulated in breast cancer cells due to $\mathrm{CpG}$ site promoter methylation. BMC Cancer 2010, 10,32 .

42. Fischer, J.R.; Ohnmacht, U.; Rieger, N.; Zemaitis, M.; Stoffregen, C.; Kostrzewa, M.; Buchholz, E.; Manegold, C.; Lahm, H. Promoter methylation of RASSF1A, RARbeta and DAPK predict poor prognosis of patients with malignant mesothelioma. Lung Cancer 2006, 54, 109-116.

43. Zou, X.P.; Zhang, B.; Zhang, X.Q.; Chen, M.; Cao, J.; Liu, W.J. Promoter hypermethylation of multiple genes in early gastric adenocarcinoma and precancerous lesions. Hum. Pathol. 2009, 40, 1534-1542.

44. Yuregir, O.O.; Yurtcu, E.; Kizilkilic, E.; Kocer, N.E.; Ozdogu, H.; Sahin, F.I. Detecting methylation patterns of p16, MGMT, DAPK and E-cadherin genes in multiple myeloma patients. Int. J. Lab. Hematol. 2010, 32, 142-149.

45. De Schutter, H.; Geeraerts, H.; Verbeken, E.; Nuyts, S. Promoter methylation of TIMP3 and CDH1 predicts better outcome in head and neck squamous cell carcinoma treated by radiotherapy only. Oncol. Rep. 2009, 21, 507-513.

46. Leung, R.C.; Liu, S.S.; Chan, K.Y.; Tam, K.F.; Chan, K.L.; Wong, L.C.; Ngan, H.Y. Promoter methylation of death-associated protein kinase and its role in irradiation response in cervical cancer. Oncol. Rep. 2008, 19, 1339-1345.

47. Kato, K.; Iida, S.; Uetake, H.; Takagi, Y.; Yamashita, T.; Inokuchi, M.; Yamada, H.; Kojima, K.; Sugihara, K. Methylated TMS1 and DAPK genes predict prognosis and response to chemotherapy in gastric cancer. Int. J. Cancer 2008, 122, 603-608. 
48. Liu, X.F.; Kong, F.M.; Xu, Z.; Yu, S.P.; Sun, F.B.; Zhang, C.S.; Huang, Q.X.; Zhou, X.T.; Song, Z.W. Promoter hypermethylation of death-associated protein kinase gene in cholangiocarcinoma. Hepatobiliary Pancreat. Dis. Int. 2007, 6, 407-411.

49. Kuester, D.; Dar, A.A.; Moskaluk, C.C.; Krueger, S.; Meyer, F.; Hartig, R.; Stolte, M.; Malfertheiner, P.; Lippert, H.; Roessner, A.; et al. Early involvement of death-associated protein kinase promoter hypermethylation in the carcinogenesis of Barrett's esophageal adenocarcinoma and its association with clinical progression. Neoplasia 2007, 9, 236-245.

50. Kong, W.J.; Zhang, S.; Guo, C.K.; Wang, Y.J.; Chen, X.; Zhang, S.L.; Zhang, D.; Liu, Z.; Kong, W. Effect of methylation-associated silencing of the death-associated protein kinase gene on nasopharyngeal carcinoma. Anticancer Drugs 2006, 17, 251-259.

51. Mittag, F.; Kuester, D.; Vieth, M.; Peters, B.; Stolte, B.; Roessner, A.; Schneider-Stock, R. DAPK promotor methylation is an early event in colorectal carcinogenesis. Cancer Lett. 2006, 240, 69-75.

52. Bai, T.; Tanaka, T.; Yukawa, K.; Maeda, M.; Umesaki, N. Reduced expression of deathassociated protein kinase in human uterine and ovarian carcinoma cells. Oncol. Rep. 2004, 11, 661-665.

53. Toyooka, S.; Toyooka, K.O.; Miyajima, K.; Reddy, J.L.; Toyota, M.; Sathyanarayana, U.G.; Padar, A.; Tockman, M.S.; Lam, S.; Shivapurkar, N.; et al. Epigenetic down-regulation of deathassociated protein kinase in lung cancers. Clin. Cancer Res. 2003, 9, 3034-3041.

54. Pal, R.; Srivastava, N.; Chopra, R.; Gochhait, S.; Gupta, P.; Prakash, N.; Agarwal, G.; Bamezai, R.N. Investigation of DNA damage response and apoptotic gene methylation pattern in sporadic breast tumors using high throughput quantitative DNA methylation analysis technology. Mol. Cancer 2010, 9, 303.

55. Suzuki, M.; Shigematsu, H.; Shivapurkar, N.; Reddy, J.; Miyajima, K.; Takahashi, T.; Gazdar, A.F.; Frenkel, E.P. Methylation of apoptosis related genes in the pathogenesis and prognosis of prostate cancer. Cancer Lett. 2006, 242, 222-230.

56. Teodoridis, J.M.; Hall, J.; Marsh, S.; Kannall, H.D.; Smyth, C.; Curto, J.; Siddiqui, N.; Gabra, H.; McLeod, H.L.; Strathdee, G.; et al. CpG island methylation of DNA damage response genes in advanced ovarian cancer. Cancer Res. 2005, 65, 8961-8967.

57. Shivapurkar, N.; Toyooka, S.; Toyooka, K.O.; Reddy, J.; Miyajima, K.; Suzuki, M.; Shigematsu, H.; Takahashi, T.; Parikh, G.; Pass, H.I.; et al. Aberrant methylation of trail decoy receptor genes is frequent in multiple tumor types. Int. J. Cancer 2004, 109, 786-792.

58. Van Noesel, M.M.; Van Bezouw, S.; Salomons, G.S.; Voute, P.A.; Pieters, R.; Baylin, S.B.; Herman, J.G.; Versteeg, R. Tumor-specific down-regulation of the tumor necrosis factor-related apoptosis-inducing ligand decoy receptors DcR1 and DcR2 is associated with dense promoter hypermethylation. Cancer Res. 2002, 62, 2157-2161.

59. Bae, S.I.; Cheriyath, V.; Jacobs, B.S.; Reu, F.J.; Borden, E.C. Reversal of methylation silencing of Apo2L/TRAIL receptor 1 (DR4) expression overcomes resistance of SK-MEL-3 and SKMEL-28 melanoma cells to interferons (IFNs) or Apo2L/TRAIL. Oncogene 2008, 27, 490-498. 
60. Horak, P.; Pils, D.; Haller, G.; Pribill, I.; Roessler, M.; Tomek, S.; Horvat, R.; Zeillinger, R.; Zielinski, C.; Krainer, M. Contribution of epigenetic silencing of tumor necrosis factor-related apoptosis inducing ligand receptor 1 (DR4) to TRAIL resistance and ovarian cancer. Mol. Cancer Res. 2005, 3, 335-343.

61. Van Noesel, M.M.; Van Bezouw, S.; Voute, P.A.; Herman, J.G.; Pieters, R.; Versteeg, R. Clustering of hypermethylated genes in neuroblastoma. Genes Chromosomes Cancer 2003, 38, 226-233.

62. Wu, J.; Wood, G.S. Reduction of Fas/CD95 promoter methylation, upregulation of Fas protein, and enhancement of sensitivity to apoptosis in cutaneous T-cell lymphoma. Arch. Dermatol. 2011, 147, 443-449.

63. Chaopatchayakul, P.; Jearanaikoon, P.; Yuenyao, P.; Limpaiboon, T. Aberrant DNA methylation of apoptotic signaling genes in patients responsive and nonresponsive to therapy for cervical carcinoma. Am. J. Obstet. Gynecol. 2010, 202, e1-e9.

64. Petak, I.; Danam, R.P.; Tillman, D.M.; Vernes, R.; Howell, S.R.; Berczi, L.; Kopper, L.; Brent, T.P.; Houghton, J.A. Hypermethylation of the gene promoter and enhancer region can regulate Fas expression and sensitivity in colon carcinoma. Cell Death. Differ. 2003, 10, 211-217.

65. Hopkins-Donaldson, S.; Ziegler, A.; Kurtz, S.; Bigosch, C.; Kandioler, D.; Ludwig, C.; Zangemeister-Wittke, U.; Stahel, R. Silencing of death receptor and caspase-8 expression in small cell lung carcinoma cell lines and tumors by DNA methylation. Cell Death Differ. 2003, 10, 356-364.

66. Obata, T.; Toyota, M.; Satoh, A.; Sasaki, Y.; Ogi, K.; Akino, K.; Suzuki, H.; Murai, M.; Kikuchi, T.; Mita, H.; et al. Identification of HRK as a target of epigenetic inactivation in colorectal and gastric cancer. Clin. Cancer Res. 2003, 9, 6410-6418.

67. Nakamura, M.; Ishida, E.; Shimada, K.; Nakase, H.; Sakaki, T.; Konishi, N. Frequent HRK inactivation associated with low apoptotic index in secondary glioblastomas. Acta Neuropathol. 2005, 110, 402-410.

68. Nakamura, M.; Ishida, E.; Shimada, K.; Nakase, H.; Sakaki, T.; Konishi, N. Defective expression of HRK is associated with promoter methylation in primary central nervous system lymphomas. Oncology 2006, 70, 212-221.

69. Higuchi, T.; Nakamura, M.; Shimada, K.; Ishida, E.; Hirao, K.; Konishi, N. HRK inactivation associated with promoter methylation and LOH in prostate cancer. Prostate 2008, 68, 105-113.

70. Zheng, S.; Houseman, E.A.; Morrison, Z.; Wrensch, M.R.; Patoka, J.S.; Ramos, C.; Haas-Kogan, D.A.; McBride, S.; Marsit, C.J.; Christensen, B.C.; et al. DNA hypermethylation profiles associated with glioma subtypes and EZH2 and IGFBP2 mRNA expression. Neuro. Oncol. 2011, 13, 280-289.

71. Velasco, A.; Pallares, J.; Santacana, M.; Gatius, S.; Fernandez, M.; Domingo, M.; Valls, J.; Yeramian, A.; Encinas, M.; Dolcet, X.; et al. Promoter hypermethylation and expression of sprouty 2 in endometrial carcinoma. Hum. Pathol. 2011, 42, 185-193.

72. Trankenschuh, W.; Puls, F.; Christgen, M.; Albat, C.; Heim, A.; Poczkaj, J.; Fleming, P.; Kreipe, H.; Lehmann, U. Frequent and distinct aberrations of DNA methylation patterns in fibrolamellar carcinoma of the liver. PLoS One 2010, 5, e13688. 
73. Jing, F.; Yuping, W.; Yong, C.; Jie, L.; Jun, L.; Xuanbing, T.; Lihua, H. CpG island methylator phenotype of multigene in serum of sporadic breast carcinoma. Tumour Biol. 2010, 31, 321-331.

74. Juhlin, C.C.; Kiss, N.B.; Villablanca, A.; Haglund, F.; Nordenstrom, J.; Hoog, A.; Larsson, C. Frequent promoter hypermethylation of the APC and RASSF1A tumour suppressors in parathyroid tumours. PLoS One 2010, 5, e9472.

75. Wang, T.; Liu, H.; Chen, Y.; Liu, W.; Yu, J.; Wu, G. Methylation associated inactivation of RASSF1A and its synergistic effect with activated K-Ras in nasopharyngeal carcinoma. J. Exp. Clin. Cancer Res. 2009, 28, 160.

76. Niklinska, W.; Naumnik, W.; Sulewska, A.; Kozlowski, M.; Pankiewicz, W.; Milewski, R. Prognostic significance of DAPK and RASSF1A promoter hypermethylation in non-small cell lung cancer (NSCLC). Folia Histochem. Cytobiol. 2009, 47, 275-280.

77. Tian, Y.; Hou, Y.; Zhou, X.; Cheng, H.; Zhou, R. Tumor suppressor RASSF1A promoter: p53 binding and methylation. PLoS One 2011, 6, e17017.

78. Tellez, C.S.; Shen, L.; Estecio, M.R.; Jelinek, J.; Gershenwald, J.E.; Issa, J.P. CpG island methylation profiling in human melanoma cell lines. Melanoma Res. 2009, 19, 146-155.

79. Ahlquist, T.; Bottillo, I.; Danielsen, S.A.; Meling, G.I.; Rognum, T.O.; Lind, G.E.; Dallapiccola, B.; Lothe, R.A. RAS signaling in colorectal carcinomas through alteration of RAS, RAF, NF1, and/or RASSF1A. Neoplasia 2008, 10, 680-686.

80. Honda, S.; Haruta, M.; Sugawara, W.; Sasaki, F.; Ohira, M.; Matsunaga, T.; Yamaoka, H.; Horie, H.; Ohnuma, N.; Nakagawara, A.; et al. The methylation status of RASSF1A promoter predicts responsiveness to chemotherapy and eventual cure in hepatoblastoma patients. Int. J. Cancer 2008, 123, 1117-1125.

81. Cohen, Y.; Merhavi-Shoham, E.; Avraham, R.B.; Frenkel, S.; Pe'er, J.; Goldenberg-Cohen, N. Hypermethylation of $\mathrm{CpG}$ island loci of multiple tumor suppressor genes in retinoblastoma. Exp. Eye Res. 2008, 86, 201-206.

82. Lai, H.C.; Lin, Y.W.; Chang, C.C.; Wang, H.C.; Chu, T.W.; Yu, M.H.; Chu, T.Y. Hypermethylation of two consecutive tumor suppressor genes, BLU and RASSF1A, located at 3p21.3 in cervical neoplasias. Gynecol. Oncol. 2007, 104, 629-635.

83. Pfeifer, G.P.; Dammann, R. Methylation of the tumor suppressor gene RASSF1A in human tumors. Biochemistry (Mosc) 2005, 70, 576-583.

84. Watanabe, H.; Okada, G.; Ohtsubo, K.; Yao, F.; Jiang, P.H.; Mouri, H.; Wakabayashi, T.; Sawabu, N. Aberrant methylation of secreted apoptosis-related protein 2 (SARP2) in pure pancreatic juice in diagnosis of pancreatic neoplasms. Pancreas 2006, 32, 382-389.

85. Grau, E.; Martinez, F.; Orellana, C.; Canete, A.; Yanez, Y.; Oltra, S.; Noguera, R.; Hernandez, M.; Bermudez, J.D.; Castel, V. Hypermethylation of apoptotic genes as independent prognostic factor in neuroblastoma disease. Mol. Carcinog. 2011, 50, 153-162.

86. Mirza, S.; Sharma, G.; Prasad, C.P.; Parshad, R.; Srivastava, A.; Gupta, S.D.; Ralhan, R. Promoter hypermethylation of TMS1, BRCA1, ERalpha and PRB in serum and tumor DNA of invasive ductal breast carcinoma patients. Life Sci. 2007, 81, 280-287.

87. Zhang, C.; Li, H.; Zhou, G.; Zhang, Q.; Zhang, T.; Li, J.; Zhang, J.; Hou, J.; Liew, C.T.; Yin, D. Transcriptional silencing of the TMS1/ASC tumour suppressor gene by an epigenetic mechanism in hepatocellular carcinoma cells. J. Pathol. 2007, 212, 134-142. 
88. Liu, X.F.; Zhu, S.G.; Zhang, H.; Xu, Z.; Su, H.L.; Li, S.J.; Zhou, X.T. The methylation status of the TMS1/ASC gene in cholangiocarcinoma and its clinical significance. Hepatobiliary Pancreat. Dis. Int. 2006, 5, 449-453.

89. Martinez, R.; Schackert, G.; Esteller, M. Hypermethylation of the proapoptotic gene TMS1/ASC: prognostic importance in glioblastoma multiforme. J. Neurooncol. 2007, 82, 133-139.

90. Terasawa, K.; Sagae, S.; Toyota, M.; Tsukada, K.; Ogi, K.; Satoh, A.; Mita, H.; Imai, K.; Tokino, T.; Kudo, R. Epigenetic inactivation of TMS1/ASC in ovarian cancer. Clin. Cancer. Res. 2004, 10, 2000-2006.

91. Yokoyama, T.; Sagara, J.; Guan, X.; Masumoto, J.; Takeoka, M.; Komiyama, Y.; Miyata, K.; Higuchi, K.; Taniguchi, S. Methylation of ASC/TMS1, a proapoptotic gene responsible for activating procaspase-1, in human colorectal cancer. Cancer Lett. 2003, 202, 101-108.

92. Guan, X.; Sagara, J.; Yokoyama, T.; Koganehira, Y.; Oguchi, M.; Saida, T.; Taniguchi, S. ASC/TMS1, a caspase-1 activating adaptor, is downregulated by aberrant methylation in human melanoma. Int. J. Cancer 2003, 107, 202-208.

93. Virmani, A.; Rathi, A.; Sugio, K.; Sathyanarayana, U.G.; Toyooka, S.; Kischel, F.C.; Tonk, V.; Padar, A.; Takahashi, T.; Roth, J.A.; et al. Aberrant methylation of TMS1 in small cell, non small cell lung cancer and breast cancer. Int. J. Cancer 2003, 106, 198-204.

94. Ramachandran, K.; Miller, H.; Gordian, E.; Rocha-Lima, C.; Singal, R. Methylation-mediated silencing of TMS1 in pancreatic cancer and its potential contribution to chemosensitivity. Anticancer Res. 2010, 30, 3919-3925.

95. Cai, H.H.; Sun, Y.M.; Miao, Y.; Gao, W.T.; Peng, Q.; Yao, J.; Zhao, H.L. Aberrant methylation frequency of TNFRSF10C promoter in pancreatic cancer cell lines. Hepatobiliary Pancreat. Dis. Int. 2011, 10, 95-100.

96. Chung, S.K.; Lee, M.G.; Ryu, B.K.; Lee, J.H.; Han, J.; Byun, D.S.; Chae, K.S.; Lee, K.Y.; Jang, J.Y.; Kim, H.J.; Chi, S.G. Frequent alteration of XAF1 in human colorectal cancers: implication for tumor cell resistance to apoptotic stresses. Gastroenterology 2007, 132, 2459-2477.

97. Murphy, T.M.; Perry, A.S.; Lawler, M. The emergence of DNA methylation as a key modulator of aberrant cell death in prostate cancer. Endocr. Relat. Cancer 2008, 15, 11-25.

98. Kempkensteffen, C.; Hinz, S.; Schrader, M.; Christoph, F.; Magheli, A.; Krause, H.; Schostak, M.; Miller, K.; Weikert, S. Gene expression and promoter methylation of the XIAP-associated Factor 1 in renal cell carcinomas: correlations with pathology and outcome. Cancer Lett. 2007, 254, 227-235.

99. Byun, D.S.; Cho, K.; Ryu, B.K.; Lee, M.G.; Kang, M.J.; Kim, H.R.; Chi, S.G. Hypermethylation of XIAP-associated factor 1, a putative tumor suppressor gene from the 17p13.2 locus, in human gastric adenocarcinomas. Cancer Res. 2003, 63, 7068-7075.

100. Chen, X.Y.; He, Q.Y.; Guo, M.Z. XAF1 is frequently methylated in human esophageal cancer. World J. Gastroenterol. 2012, 18, 2844-2849.

101. Butler, L.M.; Dobrovic, A.; Bianco, T.; Cowled, P.A. Promoter region methylation does not account for the frequent loss of expression of the Fas gene in colorectal carcinoma. Br. J. Cancer. 2000, 82, 131-135. 
102. Kurita, S.; Higuchi, H.; Saito, Y.; Nakamoto, N.; Takaishi, H.; Tada, S.; Saito, H.; Gores, G.J.; Hibi, T. DNMT1 and DNMT3b silencing sensitizes human hepatoma cells to TRAIL-mediated apoptosis via up-regulation of TRAIL-R2/DR5 and caspase-8. Cancer Sci. 2010, 101, 1431-1439.

103. Liedtke, C.; Zschemisch, N.H.; Cohrs, A.; Roskams, T.; Borlak, J.; Manns, M.P.; Trautwein, C. Silencing of caspase- 8 in murine hepatocellular carcinomas is mediated via methylation of an essential promoter element. Gastroenterology 2005, 129, 1602-1615.

104. Teitz, T.; Wei, T.; Valentine, M.B.; Vanin, E.F.; Grenet, J.; Valentine, V.A.; Behm, F.G.; Look, A.T.; Lahti, J.M.; Kidd, V.J. Caspase 8 is deleted or silenced preferentially in childhood neuroblastomas with amplification of MYCN. Nat. Med. 2000, 6, 529-535.

105. Stone, A.R.; Bobo, W.; Brat, D.J.; Devi, N.S.; Van Meir, E.G.; Vertino, P.M. Aberrant methylation and down-regulation of TMS1/ASC in human glioblastoma. Am. J. Pathol. 2004, $165,1151-1161$.

106. Siraj, A.K.; Hussain, A.R.; Al-Rasheed, M.; Ahmed, M.; Bavi, P.; Alsobhi, S.A.; Al-Nuaim, A.; Uddin, S.; Al-Kuraya, K. Demethylation of TMS1 gene sensitizes thyroid cancer cells to TRAILinduced apoptosis. J. Clin. Endocrinol. Metab. 2011, 96, E215-E224.

107. Collard, R.L.; Harya, N.S.; Monzon, F.A.; Maier, C.E.; O'Keefe, D.S. Methylation of the ASC gene promoter is associated with aggressive prostate cancer. Prostate 2006, 66, 687-695.

108. Das, P.M.; Ramachandran, K.; Vanwert, J.; Ferdinand, L.; Gopisetty, G.; Reis, I.M.; Singal, R. Methylation mediated silencing of TMS1/ASC gene in prostate cancer. Mol. Cancer. 2006, 5, 28.

109. Conway, K.E.; McConnell, B.B.; Bowring, C.E.; Donald, C.D.; Warren, S.T.; Vertino, P.M. TMS1, a novel proapoptotic caspase recruitment domain protein, is a target of methylationinduced gene silencing in human breast cancers. Cancer Res. 2000, 60, 6236-6242.

110. Kim, S.J.; Kelly, W.K.; Fu, A.; Haines, K.; Hoffman, A.; Zheng, T.; Zhu, Y. Genome-wide methylation analysis identifies involvement of TNF-alpha mediated cancer pathways in prostate cancer. Cancer Lett. 2011, 302, 47-53.

111. Nakamura, M.; Shimada, K.; Konishi, N. The role of HRK gene in human cancer. Oncogene 2008, 27 Suppl 1, S105-S113.

112. Dai, Z.; Liu, S.; Marcucci, G.; Sadee, W. 5-Aza-2'-deoxycytidine and depsipeptide synergistically induce expression of BIK (BCL2-interacting killer). Biochem. Biophys. Res. Commun. 2006, 351, 455-461.

113. Christoph, F.; Hinz, S.; Kempkensteffen, C.; Weikert, S.; Krause, H.; Schostak, M.; Schrader, M.; Miller, K. A gene expression profile of tumor suppressor genes commonly methylated in bladder cancer. J. Cancer Res. Clin. Oncol. 2007, 133, 343-349.

114. Fu, W.N.; Bertoni, F.; Kelsey, S.M.; McElwaine, S.M.; Cotter, F.E.; Newland, A.C.; Jia, L. Role of DNA methylation in the suppression of Apaf-1 protein in human leukaemia. Oncogene 2003, $22,451-455$.

115. Chen, Y.K.; Huse, S.S.; Lin, L.M. Expression of inhibitor of apoptosis family proteins in human oral squamous cell carcinogenesis. Head Neck 2011, 33, 985-998.

116. Esteve, P.O.; Chin, H.G.; Pradhan, S. Molecular mechanisms of transactivation and doxorubicinmediated repression of survivin gene in cancer cells. J. Biol. Chem. 2007, 282, 2615-2625.

117. Okami, J.; Simeone, D.M.; Logsdon, C.D. Silencing of the hypoxia-inducible cell death protein BNIP3 in pancreatic cancer. Cancer Res. 2004, 64, 5338-5346. 
118. Shimizu, S.; Iida, S.; Ishiguro, M.; Uetake, H.; Ishikawa, T.; Takagi, Y.; Kobayashi, H.; Higuchi, T.; Enomoto, M.; Mogushi, K.; Mizushima, H.; Tanaka, H.; Sugihara, K. Methylated BNIP3 gene in colorectal cancer prognosis. Oncol. Lett. 2010, 1, 865-872.

119. Liu, F.; Liu, Q.; Yang, D.; Bollag, W.B.; Robertson, K.; Wu, P.; Liu, K. Verticillin A overcomes apoptosis resistance in human colon carcinoma through DNA methylation-dependent upregulation of BNIP3. Cancer Res. 2011, 71, 6807-6816.

120. Deng, Q.; Huang, C.M.; Chen, N.; Li, L.; Wang, X.D.; Zhang, W.; Bi, F.; Tang, Q.L.; Li, Z.P.; Wang, W. Chemotherapy and Radiotherapy Downregulate the Activity and Expression of DNA Methyltransferase and Enhance Bcl-2/E1B-19-kDa Interacting Protein-3-Induced Apoptosis in Human Colorectal Cancer Cells. Chemotherapy 2012, 58, 445-453.

121. Zou, B.; Chim, C.S.; Zeng, H.; Leung, S.Y.; Yang, Y.; Tu, S.P.; Lin, M.C.; Wang, J.; He, H.; Jiang, S.H.; et al. Correlation between the single-site $\mathrm{CpG}$ methylation and expression silencing of the XAF1 gene in human gastric and colon cancers. Gastroenterology 2006, 131, 1835-1843.

122. Lee, M.G.; Huh, J.S.; Chung, S.K.; Lee, J.H.; Byun, D.S.; Ryu, B.K.; Kang, M.J.; Chae, K.S.; Lee, S.J.; Lee, C.H.; et al. Promoter $\mathrm{CpG}$ hypermethylation and downregulation of XAF1 expression in human urogenital malignancies: implication for attenuated p53 response to apoptotic stresses. Oncogene 2006, 25, 5807-5822.

123. Tada, Y.; Wada, M.; Taguchi, K.; Mochida, Y.; Kinugawa, N.; Tsuneyoshi, M.; Naito, S.; Kuwano, M. The association of death-associated protein kinase hypermethylation with early recurrence in superficial bladder cancers. Cancer Res. 2002, 62, 4048-4053.

124. Satoh, A.; Toyota, M.; Itoh, F.; Kikuchi, T.; Obata, T.; Sasaki, Y.; Suzuki, H.; Yawata, A.; Kusano, M.; Fujita, M.; et al. DNA methylation and histone deacetylation associated with silencing DAP kinase gene expression in colorectal and gastric cancers. Br. J. Cancer 2002, 86, 1817-1823.

125. Pulling, L.C.; Grimes, M.J.; Damiani, L.A.; Juri, D.E.; Do, K.; Tellez, C.S.; Belinsky, S.A. Dual promoter regulation of death-associated protein kinase gene leads to differentially silenced transcripts by methylation in cancer. Carcinogenesis 2009, 30, 2023-2030.

126. Puto, L.A.; Reed, J.C. Daxx represses RelB target promoters via DNA methyltransferase recruitment and DNA hypermethylation. Genes Dev. 2008, 22, 998-1010.

127. Kawai, Y.; Sakano, S.; Suehiro, Y.; Okada, T.; Korenaga, Y.; Hara, T.; Naito, K.; Matsuyama, H.; Hinoda, Y. Methylation level of the RASSF1A promoter is an independent prognostic factor for clear-cell renal cell carcinoma. Ann. Oncol. 2010, 21, 1612-1617.

128. Friedrich, M.G.; Weisenberger, D.J.; Cheng, J.C.; Chandrasoma, S.; Siegmund, K.D.; Gonzalgo, M.L.; Toma, M.I.; Huland, H.; Yoo, C.; Tsai, Y.C.; et al. Detection of methylated apoptosisassociated genes in urine sediments of bladder cancer patients. Clin. Cancer Res. 2004, 10, 7457-7465.

129. Kwong, J.; Lo, K.W.; To, K.F.; Teo, P.M.; Johnson, P.J.; Huang, D.P. Promoter hypermethylation of multiple genes in nasopharyngeal carcinoma. Clin. Cancer Res. 2002, 8, $131-137$.

130. Li, H.; Rauch, T.; Chen, Z.X.; Szabo, P.E.; Riggs, A.D.; Pfeifer, G.P. The histone methyltransferase SETDB1 and the DNA methyltransferase DNMT3A interact directly and localize to promoters silenced in cancer cells. J. Biol. Chem. 2006, 281, 19489-19500. 
131. Wang, J.; Bhutani, M.; Pathak, A.K.; Lang, W.; Ren, H.; Jelinek, J.; He, R.; Shen, L.; Issa, J.P.; Mao, L. Delta DNMT3B variants regulate DNA methylation in a promoter-specific manner. Cancer Res. 2007, 67, 10647-10652.

132. Cho, S.W.; Her, S.J.; Sun, H.J.; Choi, O.K.; Yang, J.Y.; Kim, S.W.; Kim, S.Y.; Shin, C.S. Differential effects of secreted frizzled-related proteins (sFRPs) on osteoblastic differentiation of mouse mesenchymal cells and apoptosis of osteoblasts. Biochem. Biophys. Res. Commun. 2008, 367, 399-405.

133. Yang, J.; Hu, X.; Zimmerman, M.; Torres, C.M.; Yang, D.; Smith, S.B.; Liu, K. Cutting edge: IRF8 regulates Bax transcription in vivo in primary myeloid cells. J. Immunol. 2011, 187, 4426-4430.

134. Yang, D.; Thangaraju, M.; Greeneltch, K.; Browning, D.D.; Schoenlein, P.V.; Tamura, T.; Ozato, K.; Ganapathy, V.; Abrams, S.I.; Liu, K. Repression of IFN regulatory factor 8 by DNA methylation is a molecular determinant of apoptotic resistance and metastatic phenotype in metastatic tumor cells. Cancer Res. 2007, 67, 3301-3309.

135. Lee, K.Y.; Geng, H.; Ng, K.M.; Yu, J.; van Hasselt, A.; Cao, Y.; Zeng, Y.X.; Wong, A.H.; Wang, X.; Ying, J.; et al. Epigenetic disruption of interferon-gamma response through silencing the tumor suppressor interferon regulatory factor 8 in nasopharyngeal, esophageal and multiple other carcinomas. Oncogene 2008, 27, 5267-5276.

136. Tshuikina, M.; Jernberg-Wiklund, H.; Nilsson, K.; Oberg, F. Epigenetic silencing of the interferon regulatory factor ICSBP/IRF8 in human multiple myeloma. Exp. Hematol. 2008, 36, 1673-1681.

137. Vinken, M.; Snykers, S.; Fraczek, J.; Decrock, E.; Leybaert, L.; Rogiers, V.; Vanhaecke, T. DNA methyltransferase $3 \mathrm{a}$ expression decreases during apoptosis in primary cultures of hepatocytes. Toxicol. In Vitro 2010, 24, 445-451.

138. Brenner, C.; Deplus, R.; Didelot, C.; Loriot, A.; Vire, E.; De Smet, C.; Gutierrez, A.; Danovi, D.; Bernard, D.; Boon, T.; et al. Myc represses transcription through recruitment of DNA methyltransferase corepressor. EMBO J. 2005, 24, 336-346.

139. Esteve, P.O.; Chin, H.G.; Pradhan, S. Human maintenance DNA (cytosine-5)-methyltransferase and p53 modulate expression of p53-repressed promoters. Proc. Natl. Acad. Sci. U S A 2005, 102, 1000-1005.

140. Wang, Y.A.; Kamarova, Y.; Shen, K.C.; Jiang, Z.; Hahn, M.J.; Wang, Y.; Brooks, S.C. DNA methyltransferase-3a interacts with p53 and represses p53-mediated gene expression. Cancer Biol. Ther. 2005, 4, 1138-1143.

141. Hervouet, E.; Lalier, L.; Debien, E.; Cheray, M.; Geairon, A.; Rogniaux, H.; Loussouarn, D.; Martin, S.A.; Vallette, F.M.; Cartron, P.F. Disruption of Dnmt1/PCNA/UHRF1 interactions promotes tumorigenesis from human and mice glial cells. PLoS One 2010, 5, e11333.

142. Hervouet, E.; Vallette, F.M.; Cartron, P.F. Dnmt3/transcription factor interactions as crucial players in targeted DNA methylation. Epigenetics 2009, 4, 487-499.

143. Hervouet, E.; Nadaradjane, A.; Gueguen, M.; Vallette, F.M.; Cartron, P.F. Kinetics of DNA methylation inheritance by the Dnmt1-including complexes during the cell cycle. Cell. Div. 2012, 7, 5 . 
144. Chen, H.; Tu, S.W.; Hsieh, J.T. Down-regulation of human DAB2IP gene expression mediated by polycomb Ezh2 complex and histone deacetylase in prostate cancer. J. Biol. Chem. 2005, 280, 22437-22444.

145. Saito, Y.; Jones, P.A. Epigenetic activation of tumor suppressor microRNAs in human cancer cells. Cell Cycle 2006, 5, 2220-2222.

146. Bhatnagar, N.; Li, X.; Padi, S.K.; Zhang, Q.; Tang, M.S.; Guo, B. Downregulation of miR-205 and miR-31 confers resistance to chemotherapy-induced apoptosis in prostate cancer cells. Cell Death Dis. 2010, 1, e105.

147. Wang, F.; Liu, M.; Li, X.; Tang, H. MiR-214 reduces cell survival and enhances cisplatininduced cytotoxicity via down-regulation of Bcl212 in cervical cancer cells. FEBS Lett. 2013, $587,488-495$.

148. Hermeking, H. The miR-34 family in cancer and apoptosis. Cell Death Differ. 2010, 17, 193-199.

149. Lee, T.L.; Leung, W.K.; Chan, M.W.; Ng, E.K.; Tong, J.H.; Lo, K.W.; Chung, S.C.; Sung, J.J.; To, K.F. Detection of gene promoter hypermethylation in the tumor and serum of patients with gastric carcinoma. Clin. Cancer Res. 2002, 8, 1761-1766.

150. Chen, D.; Wan, S.B.; Yang, H.; Yuan, J.; Chan, T.H.; Dou, Q.P. EGCG, green tea polyphenols and their synthetic analogs and prodrugs for human cancer prevention and treatment. Adv. Clin. Chem. 2011, 53, 155-177.

151. Li, Y.; Tollefsbol, T.O. Impact on DNA methylation in cancer prevention and therapy by bioactive dietary components. Curr. Med. Chem. 2010, 17, 2141-2151.

152. Khan, S.I.; Aumsuwan, P.; Khan, I.A.; Walker, L.A.; Dasmahapatra, A.K. Epigenetic events associated with breast cancer and their prevention by dietary components targeting the epigenome. Chem. Res. Toxicol. 2012, 25, 61-73.

153. Singh, V.; Sharma, P.; Capalash, N. DNA methyltransferase inhibitors as epigenetic therapy for cancer. Curr. Cancer Drug Targets 2013.

154. Khan, R.; Schmidt-Mende, J.; Karimi, M.; Gogvadze, V.; Hassan, M.; Ekstrom, T.J.; Zhivotovsky, B.; Hellstrom-Lindberg, E. Hypomethylation and apoptosis in 5-azacytidine-treated myeloid cells. Exp. Hematol. 2008, 36, 149-157.

155. Eramo, A.; Pallini, R.; Lotti, F.; Sette, G.; Patti, M.; Bartucci, M.; Ricci-Vitiani, L.; Signore, M.; Stassi, G.; Larocca, L.M.; et al. Inhibition of DNA methylation sensitizes glioblastoma for tumor necrosis factor-related apoptosis-inducing ligand-mediated destruction. Cancer Res. 2005, 65, 11469-11477.

156. Yang, D.; Torres, C.M.; Bardhan, K.; Zimmerman, M.; McGaha, T.L.; Liu, K. Decitabine and vorinostat cooperate to sensitize colon carcinoma cells to Fas ligand-induced apoptosis in vitro and tumor suppression in vivo. J. Immunol. 2012, 188, 4441-4449.

157. Hervouet, E.; Debien, E.; Campion, L.; Charbord, J.; Menanteau, J.; Vallette, F.M.; Cartron, P.F. Folate supplementation limits the aggressiveness of glioma via the remethylation of DNA repeats element and genes governing apoptosis and proliferation. Clin. Cancer Res. 2009, 15, 3519-3529.

158. Park, C.S.; Cho, K.; Bae, D.R.; Joo, N.E.; Kim, H.H.; Mabasa, L.; Fowler, A.W. Methyl-donor nutrients inhibit breast cancer cell growth. In Vitro Cell Dev. Biol. Anim. 2008, 44, 268-272. 
159. Cartron, P.F.; Hervouet, E.; Debien, E.; Olivier, C.; Pouliquen, D.; Menanteau, J.; Loussouarn, D.; Martin, S.A.; Campone, M.; Vallette, F.M. Folate supplementation limits the tumourigenesis in rodent models of gliomagenesis. Eur. J. Cancer 2012, 48, 2431-2441.

160. Gaudet, F.; Hodgson, J.G.; Eden, A.; Jackson-Grusby, L.; Dausman, J.; Gray, J.W.; Leonhardt, H.; Jaenisch, R. Induction of tumors in mice by genomic hypomethylation. Science 2003, 300, 489-492.

161. Ateeq, B.; Unterberger, A.; Szyf, M.; Rabbani, S.A. Pharmacological inhibition of DNA methylation induces proinvasive and prometastatic genes in vitro and in vivo. Neoplasia $\mathbf{2 0 0 8}$, 10, 266-278.

2013 by the authors; licensee MDPI, Basel, Switzerland. This article is an open access article distributed under the terms and conditions of the Creative Commons Attribution license (http://creativecommons.org/licenses/by/3.0/). 